\title{
CONSTITUCIÓN Y LEGISLACIÓN ANTITERRORISTA
}

\author{
POR \\ PEDRO TENORIO SÁNCHEZ \\ Profesor Titular de Derecho constitucional \\ Letrado del Tribunal Constitucional
}

\section{INTRODUCCIÓN}

El presente trabajo tiene por objeto el estudio del régimen jurídico del terrorismo, prestando particular atención a las principales resoluciones que han dictado tribunales supremos significativos, en relación con dicho fenómeno, y más concretamente las dictadas tras los atentados de 11 de septiembre de 2001.

En una primera parte se alude a las transformaciones legislativas que ha comportado la lucha contra el terrorismo, que pueden sintetizarse en lo que los constitucionalistas han descrito como una normalización del Derecho excepcional o los penalistas han estudiado dentro de la rúbrica «Derecho penal del enemigo».

En una segunda parte se analizan las principales sentencias recaídas sobre la materia con particular referencia, al menos, a cuatro Sentencias del Tribunal Supremo de EE UU (tres de 28 de junio de 2004 — Rasul v. Bush, Hamdi v. Rumsfeld, y Padilla v. Rumsfeld — y otra de 29 de junio de 2006 - Hamdan v. Rumsfeld-) y a la Sentencia de nuestro Tribunal Supremo de 20 de julio de 2006.

La tercera parte contiene una serie de reflexiones entre las que cabe destacar la idea fundamental de que debe confeccionarse en este ámbito un nuevo paradigma: el de las situaciones de tensión. Y que elementos esenciales de ese paradigma son el principio de universalidad de los derechos humanos y la jurisprudencia del Tribunal Europeo de Derechos humanos (TEDH en lo sucesivo). 


\section{LIMITACIONES DE LOS DERECHOS FUNDAMENTALES POR LA LEGISLACIÓN ANTITERRORISTA}

Los derechos fundamentales, concreción nacional estatal de los derechos humanos, vienen padeciendo una serie de limitaciones o restricciones que han sido detectados en el ámbito del Derecho público tanto por los constitucionalistas como por los penalistas.

En el ámbito del Derecho constitucional ${ }^{1}$, en efecto, se ha señalado que ya no se hace uso del Derecho de excepción porque se han introducido una serie de reformas permanentes en las leyes que rigen los períodos de normalidad que lo hacen innecesario. En el del Derecho penal, se ha señalado la aparición del llamado» Derecho penal del enemigo» ${ }^{2}$.

Comenzando por este último, en efecto, no podemos ignorar la existencia de una construcción doctrinal importante sobre esta cuestión; en numerosos ordenamientos jurídicos hay manifestaciones del Derecho penal del enemigo. Mucho antes que Jakobs estableciera su teoría penal, algunos autores se habían pronunciado sobre la existencia del «enemigo» como ciudadano que se aparta de la convivencia y reglas de la sociedad. Se han señalado en este sentido antecedentes de la construcción sobre todo en Hobbes. Centrándonos en la construcción de Jakobs, este autor parte de la necesidad de crear dos tipos de legislación penal separados: uno que se aplique a los ciudadanos, y otro que se aplique a los «enemigos». El enemigo es un individuo que, no sólo de manera incidental, en su comportamiento, o en su ocupación profesional, o principalmente a través de una organización (terrorismo, delincuencia organizada), es decir, en cualquier caso, de una forma presuntamente duradera, ha abandonado el Derecho.

La privación del carácter de persona y la atribución de la condición de enemigo es el elemento esencial sobre el que gravita toda la construcción de Jakobs. Nos encontraríamos, pues, con dos Derechos penales. Por una parte, el de los ciudadanos, que define y sanciona delitos o infracciones de normas y que busca la protección de la convivencia y de los valores de la sociedad. Derecho que, cuando en ocasiones es infringido por los ciudadanos provoca, siempre bajo los principios de intervención mínima y subsidiariedad, la iniciación de un proceso

${ }^{1}$ En este punto sigo en gran medida a De Vergottini, Giuseppe, «La difícil convivencia entre libertad y seguridad. Respuesta de las democracias al terrorismo", en Revista de Derecho Político de la UNED, n. ${ }^{\circ}$ 61, Madrid, 2004, pp. 11 y ss.

2 En este punto sigo a Ibáñez López-Pozas, Fernando y García-Montes, Marcos; «La Sentencia de 26 de julio de 2006 del Tribunal Supremo en el caso del talibán español», La Ley, n. ${ }^{\circ}$ 6628, 12 de enero de 2007, p. 1 y ss. 
para la imposición de la pena correspondiente. Y, por otra, el Derecho penal del enemigo, que se aparta de los fines ordinarios del Derecho penal y de su función rehabilitadora o de reinserción social, y que es más una legislación de lucha o de guerra que tiene como finalidad la exclusión y supresión de aquellos que, por sus conductas, forma de vida o pertenencia a una organización delictiva, renuncian de manera definitiva al sistema jurídico, lo que implica a su vez una exclusión de los beneficios que se otorgan a las personas en el sistema.

Si de la perspectiva del Derecho penal pasamos a la del constitucional, encontramos la constatación de que las constituciones no están por lo general actualizadas en cuanto al establecimiento de formas de protección respecto de emergencias como las provocadas por el terrorismo ubicuo proveniente de lugares indeterminados y, desarrollado por sujetos no necesariamente coincidentes con organizaciones de Estados territoriales, esto es, con el terrorismo internacional de carácter global. Es acaso excepción la Constitución española, condicionada en su nacimiento por el carácter endémico del terrorismo vasco, que permite a una Ley Orgánica determinar formas y casos en los que con garantías jurisdiccionales y parlamentarias pueden ser suspendidos algunos artículos «de forma individual y con la necesaria intervención judicial y el adecuado control parlamentario,... para personas determinadas, en relación con las investigaciones correspondientes a la actuación de bandas armadas o elementos terroristas» (art. 55.2), disposición originada por exigencias de defensa del terrorismo interno que sin embargo bien puede referirse al de origen exterior.

Pero con esta salvedad, todavía en la actualidad, la limitación de los derechos para hacer frente a la emergencia terrorista sigue encontrando su base constitucional en las normas destinadas a la protección de las comunidades estatales respecto de peligros de subversión, que por lo general se considera qu incluyen implícitamente la emergencia terrorista. Por lo que se refiere a los Estados europeos que han ratificado el Convenio Europeo de Derechos Humanos (CEDH en lo sucesivo), ha de recordarse que el propio Convenio permite en particulares condiciones que por razón de guerra o de otro peligro público que amenace la vida de la Nación, el Estado miembro pueda adoptar medidas suspensivas ${ }^{3}$ de las obligaciones del Convenio (art. 15). Similar es la previsión contenida en el Pacto Internacional sobre los derechos civiles y políticos de 1966 (art. 4), para la generalidad de los Estados miembros de Naciones Unidas.

${ }^{3}$ La versión española del CEDH habla de medidas que deroguen las obligaciones previstas en el convenio, pero no tiene carácter oficial (solamente tienen carácter oficial las versiones en inglés y en francés) y nos parece más adecuado traducir la expresión del convenio por suspensión en lugar de derogación, y hablar de medidas suspensivas o excepcionadoras del convenio. 
Ahora bien, la tendencia actual es que las medidas excepcionadoras no siempre se adopten poniendo en evidencia el alejamiento del régimen ordinario. No se evidencian regímenes de excepción proclamando específicos «estados». En la realidad de estos últimos años ${ }^{4}$, el problema de los límites se ha planteado prescindiendo de la instauración de un régimen jurídico de suspensión formal de las garantías, no habiéndose declarado en los Estados europeos democráticos estados de excepción. La normalización de la emergencia comporta el uso de las fuentes ordinarias y en particular de la ley en la generalidad de los ordenamientos, incluidos los que han previsto en la Constitución regímenes jurídicos de suspensión de los derechos en relación a la gestión de las emergencias.

Por otra parte, se desdibuja la distinción entre medidas destinadas a afrontar emergencias puntuales, y por tanto con plazo, y medidas destinadas a continuar en el tiempo, y por tanto tendencialmente definitivas. En los textos normativos aprobados en los últimos años para combatir la amenaza terrorista, junto a disposiciones con plazo de vigencia, se encuentran abundantes disposiciones destinadas a estar en vigor por tiempo indeterminado.

Además, tras los eventos de septiembre de 2001, la legislación antiterrorista es cada vez más amplia.

Estos fenómenos se pueden constatar tanto en Estados Unidos como en las principales democracias europeas. Cabría referirse ${ }^{5}$ a las legislaciones antiterroristas de Estados Unidos, Alemania ${ }^{6}$, Italia ${ }^{7}$, Francia $^{8}$, Gran Bretaña ${ }^{9}$ y de nues-

${ }^{4}$ Ha llamado la atención sobre este hecho De Vergottini, Giuseppe, «La difícil convivencia entre libertad y seguridad. Respuesta de las democracias al terrorismo", en Revista de Derecho Político de la UNED, n. ${ }^{\circ}$ 61, Madrid, 2004, p. 23.

5 Vergottini, Giuseppe de, Guerra e Costituzione, Bolonia, 2004, pp. 202 y ss., se refiere a las diferentes legislaciones en varios estados occidentales. También Benazzo, Antonella, L’emergenza nel conflitto fra libertà e sicurezza, G. Giappichelli Editore, Torino, 2004, pp. 23 y ss.

${ }^{6}$ Grewe, Constante \& Sommermann, Karl-Peter, «Lutte contre le terrorisme et protection des droits fondamentaux. Allemagne», Annuaire International de Justice Constitutionnelle, XVIII, 2002, pp. 72 y ss.

7 V. Baldini, V., Sicurezza e libertà nello Statu di diritto in trasformazione, Torino, 2005, pág. 73; Garuti, G., «Le intercettazioni preventive nella lotta al terrorismo internazionale», en Diritto penale e processo, 2005, pp. 1457 y ss.; Pellizonne, Irene, «Le misure anti-terrorismo internacionales e la "normalizzazione dell'emergenza" ", Giurisprudenza Costituzionale, anno LI, marzo-aprile 2006, fasc. 2, pp. 1765 y ss.

${ }^{8}$ Benazzo, Antonella, L'emergenza nel conflitto fra libertà e sicurezza, G. Giappichelli Editore, Torino, 2004, pp. 26 y ss.

9 Acerca de la analogía entre la experiencia británica y la de la Europa continental puede verse por ejemplo Baldassarre A., "Le ideologie costituzionali dei diritti di libertá», en Democrazia e diritto, 1976, pp. 265 y ss.; sobre el Derecho de emergencia británico, v. Benazzo, Antonella, L'emergenza nel conflicto fra libertà e sicurezza, G. Giappichelli Editore, Torino, 2004, pp. 59 y si- 
tro país. En este trabajo vamos a entrar sucintamente en el caso de Estados Unidos, que tiene la legislación antiterrorista más severa y controvertida, y en el nuestro.

\subsection{Estados Unidos}

Un lugar destacado ocupa, en efecto, en este ámbito, Estados Unidos ${ }^{10}$. La legislación aprobada tras septiembre de 2001 (The USA Patriot Act, de 26 de octubre de $2001^{11}$, seguida por Executive Orders presidenciales y varios reglamentos con incidencia en numerosas leyes anteriores (que son por tanto modificadas) ha limitado ampliamente derechos sustanciales y garantías de defensa para cualquiera que sea sospechoso de actividad terrorista.

La Patriot Act es larga: 166 páginas, dividida en diez partes de las que cada una trata de un tema diferente. Por lo que se refiere a los derechos fundamentales, los temas más importantes son la vigilancia, el blanqueo de dinero, el es-

guientes; acerca de la formulación histórica del esquema del bill of indemnity, ver Marazzita G., "L'emergenza costitutionale. Definizioni e modelli», Giuffré, Milano, 2000, pp. 90 y ss.; sobre los estados de crisis, Toniatti, R., "L'ordinamento costituzonale della difesa e degli stati di crisi in Gran Bretaña", en G. de Vergottini (coord.), Costituzione della difesa e stati di crisi, CeMISS, Roma, 1991, pp. 201 a 204.

${ }^{10}$ Frosini, Tommaso Edoardo, "El Estado de Derecho se ha detenido en Guantánamo ", REDC, núm. 76, CEPC, Enero/abril 2006, pp. 33 y ss.; Vroom, Cynthia; «Lutte contre le terrorisme et protection des droits fondamentaux", en Annuaire international de justice constitutionnelle, XVIII-2002, p. 162.

${ }^{11}$ El nombre correcto de la legislación es el «Uniting and Strengthening Arnerica by Providing Appropriate Tools Required to Intercept and Obstruct Terrorism Act of 2001», conocido generalmente por el acrónirno PATRIOT Act, promulgado por el 1O7th Congreso de los Estados Unidos, primera sesión, H. R. 3162, 24 de octubre de 2001, http://www.epic.org/privacv/t 162. html

La Ley contiene una serie de medidas de carácter excepcional que atribuyen al Presidente facultades en materia de vigilancia de las comunicaciones, control de fronteras y actividades financieras. Prueba su carácter excepcional el que la Ley se reconocía temporal, lo que exigió posteriormente su prórroga, que fue firmada por Bush el 9 de marzo de 2006. Sin embargo, es necesario recordar algunas cosas importantes: dieciséis de las medidas que la ley recogía expiraban el 31 de diciembre de 2005. Bush no pudo obtener la renovación de la norma en plazo por la rebelión de algunos de los senadores y congresistas republicanos debido al escándalo de las escuchas que ilegalmente había realizado la NSA, a pesar de que se suponía que la Patriot Act había concedido facultades suficientes para intervenir las comunicaciones en lo que fuera necesario. Se amplió el plazo de vigencia para llegar a un acuerdo que finalmente se alcanzó convirtiendo en permanentes catorce de las dieciséis medidas una vez que habían sido debidamente dulcificadas. 
tatuto y la detención de los extranjeros y el reforzamiento de las leyes penales. Es extraordinariamente compleja, difícil de comprender, sobre todo aisladamente, ya que modifica una quincena de leyes a las que hace falta referirse para desentrañar su sentido.

Un aspecto a destacar en la Patriot Act es que amplía los poderes de la autoridad administrativa en materia de investigaciones y acceso a los datos personales, permitiendo interceptaciones de cualquier forma de comunicación electrónica, excepcionando el derecho a la intimidad protegido por la Cuarta Enmienda ${ }^{12}$. El peligro es que esta vigilancia tenga efecto nocivo en las libertades de expresión y de asociación, que es precisamente una de las razones de la separación entre seguridad interior e inteligencia exterior, una separación tajante que implicaba la limitación de los poderes de la Agencia Central de Inteligencia que tiende a desdibujarse con la nueva regulación. En efecto, los ciudadanos americanos tienen el derecho a discrepar de la política de su Gobierno, a apoyar causas políticas impopulares y a asociarse con otros para la expresión y manifestación pacífica de dichos puntos de vista, sin tener miedo de ser investigados por el FBI, la CIA o por cualquier otra agencia del gobierno, pues las investigaciones injustificadas de la expresión política y de la discrepancia política pueden acabar teniendo un efecto debilitador sobre el sistema político en su conjunto.

Un segundo aspecto destacado de la repetida ley es la disminución de las garantías procesales reconocidas a los extranjeros, pues establece la detención preceptiva de los extranjeros si, en virtud de una certificación del Fiscal General existen razones plausibles para creer que están implicados en actividades terroristas, o en «otra actividad que presente peligro para la seguridad nacional». El extranjero puede ser detenido durante un máximo de 7 días, luego debe ser dejado en libertad o acusado. Si es susceptible de expulsión pero ésta es poco probable (por ejemplo, porque su país de origen se niegue a aceptarlo), puede ser detenido durante seis meses más si lo exigen la prevención de una amenaza para la seguridad nacional, para la comunidad o una persona. La persona detenida puede solicitar el habeas corpus, y puede apelar la decisión de detenerlo ante el Tribunal de Apelación federal.

Junto a la Patriot Act, la norma antiterrorista estadounidense más criticada, y no siempre distinguida de la referida ley, es la Orden Ejecutiva de 13 de no-

12 Enmienda IV: «El derecho de los habitantes de que sus personas, domicilios, papeles y efectos se hallen a salvo de pesquisas y aprehensiones arbitrarias, será inviolable, y no se expedirán al efecto mandamientos que no se apoyen en un motivo verosímil, estén corroborados mediante juramento o protesta y describan con particularidad el lugar que deba ser registrado y las personas o cosas que han de ser detenidas o embargadas». 
viembre de 2001, en la que el Presidente estableció comisiones militares para juzgar a los extranjeros miembros de Al-Qaeda o que hubieran participado en actividades terroristas contra Estados Unidos. Según este Reglamento, a diferencia de lo que ocurre en el proceso penal, bastaba una mayoría de dos tercios de los miembros de la Comisión para decidir una condena. También la regulación de la prueba (rules of evidence) es más laxa. En lugar de estar sometidas a los criterios de admisibilidad exigidos en el proceso penal, las pruebas tienen que tener simplemente "valor probatorio», criterio mucho menos riguroso. Además, no existe apelación judicial. Existe tan sólo una apelación al Presidente o al Secretario de Estado de Defensa.

Esta Orden Ejecutiva, que creó las comisiones militares, ha sido muy criticada, pues su ámbito, se ha dicho, es disparatadamente amplio, siendo susceptible de aplicarse mucho más allá del estrecho grupo de los líderes de Al-Qaeda en Afganistán.

Esta norma es uno de los fundamentos jurídico positivos principales sobre los que se basa la existencia de la prisión de Guantánamo, en la que las autoridades militares americanas, como es sabido, han llegado a mantener alrededor de 625 detenidos. Y ha dado lugar a cuatro pronunciamientos interesantes del Tribunal Supremo norteamericano.

El más importante de estos últimos fue el recaído el verano pasado en un recurso planteado por un preso llamado Hamdan, que había sido chófer y guardaespaldas de Osama ben Laden. El 29 de junio de 2006, el Tribunal Supremo dictó sentencia, la conocida como Hamdan v. Rumsfeld ${ }^{13}$, que declaró que tales comisiones eran ilegales por ser contrarias al Código de Justicia Militar y al común artículo 3 de las Convenciones de Ginebra.

Pero para superar esta ilegalidad se promulgó la Ley de Comisiones Militares ${ }^{14}$, que básicamente convirtió en octubre de 2006 lo que en 2001 no era más que una orden del Presidente, con lo que la situación, en sus rasgos principales, no ha cambiado.

13 Sentencia del Tribunal Supremo en el caso Hamdan, 548 US Hamdan v. Rumsfeld 2006. La Sentencia aparece acompañada de tres opiniones disidentes, de los jueces Thomas, Alito y Scalia, y por dos opiniones más, la Concurring Opinion del juez Breyer, y la Concurring in part del juez Kennedy. El texto de la Sentencia puede encontrarse en la siguiente dirección: http://www.supremecourtus.gov/opinions/05 pdf/05184.pdf\#search=\%22hamdan \%20v.\%20rumsfeld $\% 20$ appeals $\% 20$ court $\% 22$

${ }^{14}$ Gudín Rodríguez-Magariños, Faustino, «El Derecho Penal del enemigo y la Military Commissions Act de 2006: ¿¿Requiem por las garantías de los presuntos terroristas?», en Revista de Derecho y Proceso Penal, n. ${ }^{\circ}$ 17, Thomson-Aranzadi, 2007, pp. 13 y ss. 


\subsection{España}

Nuestra experiencia no se aparta sustancialmente de la evolución de los sistemas francés y alemán en lo que se refiere a las cautelas observadas en orden a la proclamación del estado de emergencia y la preferencia por la adecuación de la legislación ordinaria para la realización de las políticas de seguridad.

Como ya puso de manifiesto el profesor Giuseppe de Vergottini ${ }^{15}$ en su análisis comparado, en el Derecho antiterrorista español, cabe destacar dos peculiaridades. Por una parte, el artículo 55.2 de la Constitución española ${ }^{16}$ (en adelante, CE), y por otra la Ley de Partidos de $2002^{17}$.

15 «La difícil convivencia entre libertad y seguridad. Respuestas de las democracias al terrorismo", (traducción de Pedro J. Tenorio Sánchez), en Revista de Derecho Político de la UNED, núm 61, pp. 61 y ss., concretamente p. 27. V. también, más desarrollado, Benazzo, Antonella, L'emergenza nel conflitto fra libertá e sicurezza, G. Giappichelli editore, Torino, 2004, pp. 50 y ss.

16 Acerca de la suspensión individual de garantías y su diferenciación con la suspensión de los derechos en situaciones de crisis constitucional, v. Torres del Moral, Antonio, Principios de Derecho Constitucional español. Tomo I. Sistema de fuentes. Sistema de los derechos, 5. ${ }^{\text {e edición, Servicio }}$ de Publicaciones de la Facultad de Derecho-Universidad Complutense de Madrid, Madrid, 2004, pp. 576 y ss.; del mismo autor, Estado de Derecho y democracia de partidos, 2. ${ }^{a}$ edición, Servicio de Publicaciones de la Facultad de Derecho-Universidad Complutense de Madrid, Madrid, 2004, pp. 240 y ss. V. también Cruz Villalón, Pedro, El estado de sitio y la Constitución: la constitucionalización de la protección extraordinaria del Estado, 1789-1878, Centro de Estudios Constitucionales, Madrid, 1980; del mismo autor «El nuevo Derecho de excepción: Ley Orgánica 4/1981, de 1 de junio", REDC, n. ${ }^{\circ}$ 2, 1981, pp. 93 y ss.; del miso autor, Estados excepcionales y suspensión de garantías, Tecnos, Madrid, 1984; Fernández-Segado, Francisco, «Naturaleza y régimen legal de la suspensión general de los derechos fundamentales», RDP, n. ${ }^{\circ s} 18-19$, Madrid, 1983; del mismo autor, "La suspensión individual del ejercicio de los derechos constitucionales» REP (NE), núm. 35, Madrid, 1983; Lafuente Balle, José María, «Los estados de alarma, excepción y sitio», RDP, n. ${ }^{\text {os } 30-31, ~ M a d r i d, ~ 1990 ; ~ N a v a s ~ C a s t i l l o, ~ M a r i ́ a ~ A n t o n i a, ~ « E l ~ T r i b u n a l ~ C o n s t i t u-~}$ cional en la declaración-autorización de los estados de alarma, excepción y sitio", en Pau y Vall (Coord.), Parlamento y Justicia Constitucional, Navarra, 1997,y «Los estados excepcionales y su posible control, por el Tribunal Constitucional», en RFDUC, n. ${ }^{\circ}$ 87, Madrid, 1997; Vírgala Foruria, E., «La suspensión de derechos por terrorismo en el ordenamiento español», REDC, n. ${ }^{\circ} 40, \mathrm{Ma}-$ drid, 1994.

17 Acerca de las posturas doctrinales en relación con esta Ley, v. Torres del Moral, Antonio, «La inconstitucionalidad de los Partidos Políticos. A propósito de la Ley Orgánica 6/2002, de Partidos Políticos", Revista de Derecho Político de la Universidad Nacional de Educación a Distancia, n. ${ }^{\circ}$ 60, Madrid 2004, pp. 39 y ss. V. también Álvarez Conde, Enrique, El Derecho de partidos, Colex, Madrid, 2004; Vírgala Foruria, E. «La STS de 27 de marzo de 2003 de ilegalización de Batasuna: el estado de derecho penetra en Euskadi", en Teoría y Realidad Constitucional, n. ${ }^{\circ} 12-13$, 2003-2004, pp. 618 y ss., y Tajadura Tejada, Javier, Partidos políticos y Constitución. Un estudio de la LO 6/2002, de 27 de junio, de Partidos políticos y de la STC 48/2003, de 12 de marzo, ThomsonCivitas, Madrid, 2004. 


\subsubsection{Suspensión individual de garantías}

En efecto, el constituyente de 1978 previó, además de una serie de estados de crisis orientada a dar inderogabilidad al orden normal de las relaciones entre poderes, también la suspensión posible de algunas garantías fundamentales de los derechos individuales en el ámbito de las investigaciones relativas al terrorismo. Y así, concretamente, como hemos visto, el art. 55.2 CE dice: «una ley orgánica podrá determinar la forma y los casos en los que, de forma individual y con la necesaria intervención judicial y el adecuado control parlamentario, los derechos reconocidos en los artículos 17, apartado 2, [duración máxima de la detención: 72 horas] y 18, apartados 2 [inviolabilidad del domicilio] y 3, [secreto de las comunicaciones] pueden ser suspendidos para personas determinadas, en relación con las investigaciones correspondientes a la actuación de bandas armadas o elementos terroristas. La utilización injustificada o abusiva de las facultades reconocidas en dicha ley orgánica producirá responsabilidad penal, como violación de los derechos y libertades reconocidos por las leyes».

Ni la doctrina ni el poder legislativo han valorado muy positivamente este art. 55.2 CE, aún cuando se trata del primer precepto que, en el marco de una Constitución democráticoliberal normativa, se dedica al fenómeno del terrorismo individualizándolo incluso respecto de los estados excepcionales que, como se ha dicho, se regulan separadamente en el art. 116 y 55.1, ambos CE. Efectivamente, en el ámbito doctrinal, se ha señalado que se trata de un precepto que habría sido necesario establecer en una ley de urgencia (Sánchez Agesta ${ }^{18}$ ). Más recientemente, por ejemplo, Fernández Segado ${ }^{19}$, sigue señalando que se trata de un precepto que tiene una explicación coyuntural.

Este precepto constitucional fue desarrollado por la Ley Orgánica 11/1980, de 1 de diciembre, sobre los supuestos previstos en el art. 55.2 de la Constitución, comúnmente denominada Ley antiterrorista. Esta ley sería sustituida cuatro años después por la Ley Orgánica 9/1984, de 26 de diciembre, contra la actuación de bandas armadas y elementos terroristas y de desarrollo del art. 55.2 CE. Finalmente, la Ley Orgánica 3/1988, de 25 de mayo, de reforma del Código penal y de la Ley de enjuiciamiento criminal derogaría la Ley Orgánica 9/1984. En lo sucesivo no existirían leyes que de manera separada y orgánica

18 Sánchez Agesta, L, El sistema politico de la Constitución española de 1978, Editora Nacional, Madrid, 1980, pp. 179-180.

19 Fernández Segado, F., «Artículo 55. la suspensión de derechos», en Alzaga Villamil, Oscar (Director), Comentarios a la Constitución española de 1978, Cortes Generales-Editoriales de Derecho Reunidas, Madrid, 1996, pp. 597 y ss., especialmente pp. 627 y ss. 
desarrollaran el art. 55.2 CE. Lo que no quiere decir que no haya en nuestro ordenamiento disposiciones, en otras leyes, que dispensen un tratamiento específico al fenómeno del terrorismo, y que siguen siendo discutidas. Baste señalar que la Ley Orgánica 4/1988, de 25 de mayo, de reforma del Código penal y de la Ley de enjuiciamiento criminal fue recurrida ante el Tribunal Constitucional por el Parlamento vasco, recurso de inconstitucionalidad que dio lugar a la STC 71/1994, de 3 de marzo.

En definitiva, la regulación vigente de esta materia se encuentra, de manera vergonzante, no en leyes especiales, sino en leyes ordinarias, a partir de las Leyes Orgánicas 3 y 4/1988, de 25 de mayo, de reforma del Código penal y de la Ley de enjuiciamiento criminal, respectivamente, con las que, en definitiva, se quiere dar apariencia de trato común a algo que, con independencia de que esté justificado y encuentre su apoyo incluso en un precepto constitucional, no es sino un conjunto de normas excepcionales.

Tras los atentados de 11 de septiembre de 2001 y la decidida difusión en otros países de medidas limitadoras de los derechos fundamentales por razón de la lucha contra el terrorismo se han vuelto a aprobar entre los otros leyes antiterroristas, que siguen teniendo no obstante la pretensión de presentarse como reformas de leyes generales. En este sentido, han de mencionarse por ejemplo, la Ley 12/2003, de 21 de mayo, de prevención y bloqueo de la financiación del terrorismo, y sobre todo, las normas incluidas en la Ley Orgánica 5/2003 de 27 de mayo, de modificación de la Ley Orgánica del poder judicial, de la Ley Orgánica general penitenciaria y de la Ley de demarcación y planta, y en la Ley Orgánica 7/2003, de 30 de junio, de medidas de reforma para el cumplimiento íntegro de las penas.

Algunos autores ${ }^{20}$ consideran que la perspectiva garantista del constituyente ha sido de alguna manera traicionada en la legislación de desarrollo del art. 55.2, que ha traducido una suspensión rigurosamente circunscrita en una limitación permanente de los derechos fundamentales de los ciudadanos que va mucho más allá de los presupuestos y de las condiciones fijadas por la Constitución, determinando una situación de inconstitucionalidad que ha dado lugar a repetidas intervenciones del Tribunal Constitucional y al recurso al Tribunal Europeo de Derechos Humanos. De hecho, la primera condena de España por violación de la $\mathrm{CEDH}$ era relativa a la falta de respeto de las garantías procesales fundamentales en el curso del proceso de determinados terroristas catalanes. Además, el análisis de las leyes orgánicas de desarrollo del art. 55.2 que se han sucedido pone de

${ }^{20}$ Vírgala Foruria, E., «La suspensión de derechos por terrorismo en el ordenamiento español», en Revista Española de Derecho Constitucional, 1994, pp. 64 y ss. 
manifiesto la ausencia de previsión de específicas modalidades de control parlamentario y de una regulación que establezca las responsabilidades penales de los funcionarios responsables de eventuales abusos, como expresamente exige el art. 55.2 CE.

\subsubsection{Ley de partidos de 2002}

El otro aspecto peculiar que puede señalarse en la experiencia española, que recuerda a la alemana, consiste en la declaración de ilegalidad de los partidos que colaboran con la violencia en el marco de la lucha contra el terrorismo. En ese sentido, el Gobierno del Partido Popular aprobó, con el apoyo del Partido Socialista, la Ley Orgánica 6/2002, de 27 de junio, de partidos políticos, orientada a luchar contra la violencia terrorista. La innovación más significativa consistió en introducir la precisión de las conductas, no penales, por razón de las cuales un partido puede ser declarado ilegal y por tanto disuelto. Entre las previsiones de la que han suscitado mayores dudas cabe destacar la posible disolución de un partido por el comportamiento «reiterado y grave» de sus miembros, por medio de discursos o comunicados en el seno de las instituciones frente a la opinión pública, cuando los mismos no hayan repudiado públicamente los fines y los medios terroristas y hayan proporcionado apoyo expreso o «tácito» al terrorismo (art. 9.3).

La doctrina ${ }^{21}$ está dividida en su actitud ante la Ley de Partidos: a) algunos autores se han movido en la dirección de una argumentación sobre todo política: en este sentido, se ha señalado que la democracia tiene que defenderse por los medios más variados para garantizar el pluralismo; b) otros, como el profesor Pérez Royo, tienen una postura abiertamente crítica frente a la ley, posición que tiene su origen la sostenida por los profesores Jiménez Campo e Ignacio de Otto, secundada en buena medida por el Tribunal Constitucional y por otros autores, como el Profesor Solozábal, que sostienen que la española no es una democracia militante; en línea parecida se mueve el Profesor Bastida, que sostiene que la ley dificulta el pluralismo; c) otros ven en la ley una serie de inconstitucionalidades

${ }^{21}$ La bibliografía acerca de esta Ley es ya abundante. Sigo la síntesis que hace Torres del Moral, Antonio, «La inconstitucionalidad de los Partidos Políticos. A propósito de la Ley Orgánica 6/2002, de Partidos Políticos", Revista de Derecho Politico de la Universidad Nacional de Educación a Distancia n. ${ }^{\circ}$ 60, Madrid 2004, pp. 39 y ss. Especialmente interesante es el trabajo de Tajadura Tejada, Javier, Partidos políticos y Constitución. Un estudio de la LO 6/2002, de 27 de junio, de Partidos políticos y de la STC 48/2003, de 12 de marzo, Thomson-Civitas, Madrid, 2004. 
o defectos insalvables: Sala enjuiciadora, conceptos jurídicos demasiado vagos, etc.; en esta línea, el Profesor Aguiar ha cuestionado la ilegalización de Herri Batasuna por su mero silencio ante los crímenes de ETA; d) una postura más matizada, sin perjuicio de detectar en la ley determinados defectos, considera que la misma queda salvada, por la Sentencia interpretativa 48/2003, de 12 de marzo, del Tribunal Constitucional; en esta línea se sitúan los profesores Torres del Moral, Tajadura y Vírgala; ha sostenido entre nosotros el profesor Tajadura que el legislador orgánico ha reducido el alcance del principio de constitucionalidad de los partidos, en su dimensión externa, al control de la actividad de aquellos, renunciando expresamente a establecer límites a las ideologías o programas partidistas; pero esa opción, indica el referido autor, a pesar de lo sostenido por algunos autores y por el propio Tribunal Constitucional en su STC 48/2003, no es la única constitucionalmente posible; el legislador orgánico puede establecer también limitaciones a los fines de los partidos; dichos límites encuentran su fundamento en la existencia, en el texto constitucional, de un conjunto de valores y principios inmunes al poder de reforma, lo que la doctrina denomina límites materiales implícitos a la reforma constitucional; e) finalmente, el Profesor De Vega apoyado en el principio clásico salus populi suprema lex esto considera que, puesto que hay que partir de que el Estado es un espacio político de libertad, cuando se amenaza con destruirlo y desmembrarlo no hay que polemizar bizantinamente acerca de la constitucionalidad de las leyes, sino que hay que salvar al Estado.

\subsection{3. «Derecho penal del enemigo» entre nosotros}

Por lo demás, también en nuestro país, en definitiva, se ha desarrollado el llamado "Derecho penal del enemigo»" Éste, como es sabido, se concreta en tres orientaciones básicas: adelantamiento de la punibilidad, aumento de las penas y disminución o supresión de determinadas garantías procesales. Dentro de nuestro ordenamiento podemos comprobar la existencia de los tres elementos citados:

a) Existen una serie de delitos que anticipan la punibilidad, castigando actos que podían denominarse preparatorios de hechos que no han sucedido. Así, los comportamientos de mera colaboración con bandas u organizaciones te-

22 En este punto sigo a Ibáñez López-Pozas, Fernando y García-Montes, Marcos; «La Sentencia de 26 de julio de 2006 del Tribunal Supremo en el caso del talibán español», La Ley, Núm 6628, 12 de enero de 2007, pp. 1 y ss. 
rroristas (art. $576^{23}$ del Código Penal —en lo sucesivo CP-) y con la apología de las infracciones de terrorismo o de sus autores (art. $578 \mathrm{CP}^{24}$ ).

b) Supuestos de incremento de las penas por razón de terrorismo encontramos en múltiple preceptos de nuestro Código Penal: en el delito de estragos o de incendios del art. $571^{25}$, en el de atentado contra las personas del art. $572^{26}$,

${ }^{23}$ Artículo 576. [Actos de colaboración].

«1. Será castigado con las penas de prisión de cinco a diez años y multa de dieciocho a veinticuatro meses el que lleve a cabo, recabe o facilite, cualquier acto de colaboración con las actividades o las finalidades de una banda armada, organización o grupo terrorista.

2. Son actos de colaboración la información o vigilancia de personas, bienes o instalaciones; la construcción, el acondicionamiento, la cesión o la utilización de alojamientos o depósitos; la ocultación o traslado de personas vinculadas a las bandas armadas, organizaciones o grupos terroristas; la organización de prácticas de entrenamiento o la asistencia a ellas, y, en general, cualquier otra forma equivalente de cooperación, ayuda o mediación, económica o de otro género, con las actividades de las citadas bandas armadas, organizaciones o grupos terroristas.

Cuando la información o vigilancia de personas mencionada en el párrafo anterior ponga en peligro la vida, la integridad física, la libertad o el patrimonio de las mismas, se impondrá la pena prevista en el apartado 1, en su mitad superior. Si llegara a ejecutarse el riesgo prevenido, se castigará el hecho como coautoría o complicidad, según los casos».

24 Artículo 578. [Actos preparatorios]

«La provocación, la conspiración y la proposición para cometer los delitos previstos en los artículos 571 a 577, se castigarán con la pena inferior en uno o dos grados a la que corresponda, respectivamente, a los hechos previstos en los artículos anteriores».

25 Artículo 571. [Estragos o incendios]

«Los que perteneciendo, actuando al servicio o colaborando con bandas armadas, organizaciones o grupos cuya finalidad sea la de subvertir el orden constitucional o alterar gravemente la paz pública, cometan los delitos de estragos o de incendios tipificados en los artículos 346 y 351 , respectivamente, serán castigados con la pena de prisión de quince a veinte años, sin perjuicio de la pena que les corresponda si se produjera lesión para la vida, integridad física o salud de las personas».

${ }^{26}$ Artículo 572. [Atentado contra las personas]

«1. Los que perteneciendo, actuando al servicio o colaborando con las bandas armadas, organizaciones o grupos terroristas descritos en el artículo anterior, atentaren contra las personas, incurrirán:

1. En la pena de prisión de veinte a treinta años si causaran la muerte de una persona.

2. En la pena de prisión de quince a veinte años si causaran lesiones de las previstas en los artículos 149 y 150 o secuestraran a una persona.

3. ${ }^{\circ}$ En la pena de prisión de diez a quince años si causaran cualquier otra lesión o detuvieran ilegalmente, amenazaran o coaccionaran a una persona.

2. Si los hechos se realizaran contra las personas mencionadas en el apartado 2 del artículo 551 o contra miembros de las Fuerzas Armadas, de las Fuerzas y Cuerpos de Seguridad del Estado, Policías de las Comunidades Autónomas o de los Entes locales, se impondrá la pena en su mitad superior». 
en la tenencia o depósito de armas del art. $573^{27}$, en otros delitos aludidos en el art. $574^{28}$, en la proporción de fondos a través de delitos patrimoniales del art. $575^{29} \mathrm{o}$ en la comisión de determinados delitos sin pertenecer a banda armada como recoge el art. $577^{30} \mathrm{CP}$. Pero acaso la manifestación más sobresaliente de este fenómeno en nuestro ordenamiento sería el art. 576 CP que establece para los actos preparatorios de colaboración con bandas armadas u organizaciones terroristas una pena de cinco a diez años de prisión y, además, multa de dieciocho a veinticuatro meses, que es superior a muchas de las penas que se imponen en tipos penales que protegen la integridad física. También podemos señalar las agravaciones establecidas con base a la pertenencia de una organización para los delitos de blanqueo de capitales, contra los derechos de los ciudadanos extranjeros.

c) Respecto de la detención, dispone el art. 520 bis de la Ley de Enjuiciamiento Criminal (LECr en adelante) la posible prórroga del plazo de duración y la incomunicación del inculpado: «1. Toda persona detenida como presunto partícipe de alguno de los delitos a que se refiere el artículo 384 bis [bandas armadas o individuos terroristas] será puesta a disposición del juez competente den-

${ }^{27}$ Artículo 573. [Tenencia o depósito de armas]

«El depósito de armas o municiones o la tenencia o depósito de sustancias o aparatos explosivos, inflamables, incendiarios o asfixiantes, o de sus componentes, así como su fabricación, tráfico, transporte o suministro de cualquier forma, y la mera colocación o empleo de tales sustancias o de los medios o artificios adecuados, serán castigados con la pena de prisión de seis a diez años cuando tales hechos sean cometidos por quienes pertenezcan, actúen al servicio o colaboren con las bandas armadas, organizaciones o grupos terroristas descritos en los artículos anteriores».

28 Artículo 574. [Otros delitos]

«Los que perteneciendo, actuando al servicio o colaborando con bandas armadas, organizaciones o grupos terroristas, cometan cualquier otra infracción con alguna de las finalidades expresadas en el artículo 571, serán castigados con la pena señalada al delito o falta ejecutados en su mitad superior".

29 Artículo 575. [Proporción de fondos a través de delitos patrimoniales]

«Los que, con el fin de allegar fondos a las bandas armadas, organizaciones o grupos terroristas señalados anteriormente, o con el propósito de favorecer sus finalidades, atentaren contra el patrimonio, serán castigados con la pena superior en grado a la que correspondiere por el delito cometido, sin perjuicio de las que proceda imponer conforme a lo dispuesto en el artículo siguiente por el acto de colaboración".

30 Artículo 577. [Sin pertenencia a banda armada]

«Los que, sin pertenecer a banda armada, organización o grupo terrorista, y con la finalidad de subvertir el orden constitucional o de alterar gravemente la paz pública, cometieren homicidios, lesiones de las tipificadas en los artículos 149 ó 150, detenciones ilegales, secuestros, amenazas o coacciones contra las personas, o llevaren a cabo cualesquiera delitos de incendios, estragos o tenencia, tráfico y depósitos de armas o municiones, serán castigados con la pena que corresponda al hecho cometido, en su mitad superior». 
tro de las setenta y dos horas siguientes a la detención. No obstante, podrá prolongarse la detención el tiempo necesario para los fines investigadores, hasta un límite máximo de otras cuarenta y ocho horas, siempre que solicitada tal prórroga mediante comunicación motivada dentro de las primeras cuarenta y ocho horas desde la detención, sea autorizada por el Juez en las veinticuatro horas siguientes. Tanto la autorización cuanto la denegación de la prórroga se adoptarán en resolución motivada».

En el año 2003 se realizaron cuatro reformas del Código penal ${ }^{31}$. De entre ellas la más impactante es la que impone que en determinados supuestos un condenado cumpla una pena de cuarenta años de prisión de una forma íntegra — sin acceso a una vida en libertad en la última fase (libertad condicional) - y efectiva — sin disfrutar de permisos de salida ni de las amplias posibilidades de actividad externa que supone el tercer grado penitenciario-. Hasta entonces la pena máxima era de treinta años de prisión y las limitaciones que se establecían para su dulcificación se referían sólo al paso a la situación de libertad condicional. Esta pena de prisión de cuarenta años fue introducida por la Ley Orgánica 7/2003, de 30 de junio, de medidas de reforma para el cumplimiento íntegro y efectivo de las penas ${ }^{32}$.

31 Sigo aquí, en parte, a Lascuraín Sánchez, Juan Antonio, “¿Que les corten la cabeza?», en Claves de Razón práctica, n. ${ }^{\circ} 145$, septiembre 2004, pp. 37 y ss.

32 Esta norma, que gozó del apoyo parlamentario del Partido Socialista, vino pronto acompañada de otras tres, ya sin dicho respaldo, en su tarea de modificación del Código Penal. La primera de ellas fue la Ley Orgánica 11/2003, de 29 de septiembre, de medidas concretas en materia de seguridad ciudadana, violencia doméstica e integración social de los extranjeros, y tiene como contenido penal principal la agravación de las penas en los supuestos de reincidencia y habitualidad, el aumento de los casos en los que la prisión de extranjeros sin permiso de residencia debe ser sustituida por su expulsión, y, sólo aquí con el apoyo del entonces principal partido de la oposición, un tratamiento penal más severo de la violencia doméstica. En segundo lugar, de la Ley Orgánica 20/2003, de 23 de diciembre, de modificación de la Ley Orgánica del Poder Judicial y del Código Penal, que aprovechó la tramitación del Ley de Arbitraje en el Senado para introducir en el Código Penal los polémicos delitos de convocatoria irregular de referenda (luego derogado por. La Ley Orgánica 2/2005, de 22 de junio) y de financiación de partidos políticos disueltos por conductas relacionadas con actividades terroristas. Anterior a esta ley orgánica, pero de vigencia posterior, es, en fin, la Ley Orgánica 15/2003, de 25 de noviembre, por la que se modifica la Ley Orgánica 10/1995, de 23 de noviembre, del Código Penal. Esta norma, que afecta a casi doscientos artículos del Código Penal, reforma el sistema de penas, suprimiendo el arresto de fin de semana, introduciendo la pena de localización permanente y rebajando el límite mínimo de la pena de prisión de seis a tres meses. Aprovecha asimismo esta ley orgánica para realizar algunas modificaciones en el catálogo de delitos. 


\section{CONTROL JURISDICCIONAL DE LAS LIMITACIONES DE LOS DERECHOS FUNDAMENTALES INTRODUCIDAS POR LA LEGISLACIÓN ANTITERRORISTA. RESOLUCIONES MÁS DESTACADAS DE DIFERENTES TRIBUNALES}

En esta segunda parte nos referiremos a las resoluciones más destacadas de diferentes tribunales en las que se controla la legislación o la política antiterrorista, comenzando por EE UU, y aludiendo a los principales países europeos. Más concretamente, comenzamos haciendo una comparación entre el Tribunal Supremo de Estados Unidos y el Tribunal Europeo de Derechos Humanos para referirnos a continuación a algunas resoluciones de Tribunales Supremos u órganos similares de otros países, como la República Federal Alemana, Francia, Gran Bretaña, y nuestro país.

\subsection{Garantismo del Tribunal Supremo de EEUU con anterioridad a los atentados de 11 de septiembre de 2001.}

Con anterioridad a los atentados de 11 de septiembre de 2001 el Tribunal Supremo de EE UU podía jactarse en muchos sentidos de ser más garantista que los tribunales europeos, y en particular que el TEDH.

3.1.1. Cuando el Tribunal Supremo de EE UU ha enfocado la cuestión de los límites de los derechos fundamentales por razón de seguridad como un conflicto entre tales derechos fundamentales y sus límites se ha decantado, en términos generales, por una interpretación amplia de los derechos, al menos con anterioridad a los atentados de 11 de septiembre de 2001. Naturalmente, no es posible realizar un repaso de la doctrina del Tribunal Supremo de EE UU en torno a los límites de los derechos fundamentales, pero sí vamos a referirnos a una Sentencia que podemos considerar emblemática en este ámbito, en la que se planteó de una manera clara, en definitiva, una colisión entre la libertad de información y la seguridad del Estado: New York Times Co. v. United States (1971) ${ }^{33}$.

33 Votada el 30 de junio de 1971 per curiam. Voto particular concurrente con el fallo de los jueces Black —al que se adhiere Douglas_, Douglas — al que se adhiere Black_, Brennan, Stewart —al que se adhiere White-, White —al que se adhiere Stewart y Marshall—. Votos particulares discrepantes del Chief Justíce Burger y del juez Harlan —al que se adhieren los jueces Burger y Blackmun-. Sigo en este punto la excelente exposición de Beltrán de Felipe, Miguel y González García, Julio V., Las sentencias básicas del Tribunal Supremo de los Estados Unidos de Amé- 
Esta Sentencia dio respuesta a una de las controversias de más importancia que ha tenido el Tribunal Supremo de EE UU: la divulgación por parte de dos importantes medios de comunicación, el New York Times y el Washington Post, de documentos que el Gobierno había clasificado como secretos.

La Sentencia debe enmarcarse en un contexto político de extraordinaria gravedad: la intervención militar de los Estados Unidos en el sudeste asiático. En 1967 el Secretario de Defensa del Presidente Johnson, Robert McNamara, había encargado a un grupo de expertos analizar las razones y la historia de la implicación estadounidense en esta área del mundo. El resultado fueron siete mil páginas, conocidas como "los papeles del Pentágono», que ponían de manifiesto la estrategia de ocultación con la que había funcionado el Gobierno norteamericano tanto frente a la opinión pública como hacia al Congreso en relación con la guerra de Vietnam.

Era pues normal que el documento fuese calificado como secreto. No obstante, los documentos llegaron al presidente de la Comisión de Asuntos Exteriores del Senado y después al New York Times y al Washington Post. La filtración provino de uno de los autores del documento, antiguo funcionario del Pentágono. El 13 de junio de 1971, después de meses de análisis, el New York Times inició su publicación, y cinco días después lo hizo el Washington Post. Parece que el Gobierno de Nixon inicialmente no pensó en intentar impedir la publicación: al fin y al cabo se trataba de un informe que ponía en tela de juicio la política del partido demócrata. Pero enseguida Nixon, aconsejado por Henry Kissinger (a la sazón Consejero Nacional de Defensa), pensó que permitir su difusión crearía un grave precedente. Así que el 15 de junio de 1971 el Gobierno estadounidense acudió a la justicia solicitando que se prohibiese a ambos diarios la publicación de más extractos, dado que su divulgación podría poner en "peligro grave e inmediato" la seguridad de Estados Unidos, conforme exige la doctrina jurisprudencial americana, mucho más respetuosa con las libertades informativas que la europea del TEDH.

Los argumentos del Gobierno eran muy claros: no sólo se estaba divulgando un material clasificado secreto (cosa que podía considerarse delito), sino que la

rica, Centro de Estudios Políticos y Constitucionales - BOE, Madrid, 2005, pp. 357 y ss. V. también Revenga Sánchez, Miguel, El imperio de la politica. Seguridad nacional y secreto de Estado en el sistema constitucional norteamericano, Ariel, Barcelona, 1995, pp. 42 y ss., y. con menor detalle, «Razonamiento judicial, seguridad nacional y secreto de Estado», REDC núm. 53 (1998), p. 66; Villaverde Menéndez, Ignacio, Estado democrático e información: el derecho a ser informado, Junta General del Principado de Asturias, Oviedo, 1994, pp. 73 y 94; Santolaya Machetti, Pablo, «El control de los secretos de Estado: la experiencia en Derecho comparado», Poder Judicial núm. 40 (1997), p. 69. 
publicación ponía en peligro las vidas de los soldados americanos y la paz en Asia.

Pues bien, el Tribunal Supremo dijo que los dos periódicos tenían derecho a publicar los "papeles del Pentágono»: no había "peligro grave e inmediato" para la seguridad de Estados Unidos.

Así resumido este caso, para percibir el contraste entre la postura liberal y abierta del Tribunal Supremo de Estados Unidos en los supuestos de colisión entre la libertad de información y la seguridad del Estado, que hemos visto plasmada en el caso New York Times v. Estados Unidos, cabe traer a colación como contrapunto la STEDH de 26 de noviembre de 1991, asunto Observer y Guardian c. Reino Unido.

3.1.2. Este último caso se refería a las prohibiciones cautelares impuestas por los jueces británicos, a instancias del Gobierno del mismo país, a los diarios The Observer y The Guardian así como a los redactores jefes de ambos diarios y a un reportero, para publicar información contenida en el libro Spycatcher, así como determinadas informaciones procedentes del autor del volumen. El libro contenía las memorias de éste último, que había sido un importante agente de los servicios de seguridad británicos (MI5) más de veinte años, en las que se hablaba de los métodos y del personal de los referidos servicios, relatando actividades ilegales llevadas a cabo para derribar al Gobierno laborista de 1974 a 1979, robos e instalaciones de micrófonos en embajadas de países aliados y hostiles, otras actividades ilegales y secretas planificadas y ejecutadas tanto en el país como en el extranjero, así como la afirmación de que la persona que había dirigido los Servicios británicos en el momento en que el autor del libro había dimitido, era un agente soviético.

El TEDH distinguió dos períodos en el lapso de tiempo en que las publicaciones habían estado prohibidas: un primer período, de aproximadamente un año de duración, durante el cual los diferentes órganos judiciales que habían intervenido habían mantenido la prohibición, pero el libro no había sido publicado en ningún país y por lo tanto la prohibición era eficaz, pues impedía la divulgación de la información; y un período de tres meses posterior, en que los órganos judiciales habían mantenido la prohibición pero el libro ya había sido publicado en Estados Unidos y adquirido por muchas personas en el Reino Unido. En este segundo período, el Tribunal consideró que la medida ya no podía considerarse "necesaria en una sociedad democrática», como exige el CEDH. Repárese, por tanto, en que el TEDH, consideró que, mientras la prohibición tenía efecto útil, era conforme al Convenio Europeo primar las razones de seguridad nacional esgrimidas por el Gobierno británico y atendidas por los Tribunales de dicho país, frente a la libertad de información. 


\subsection{El Tribunal Supremo de EEUU tras los atentados de 11 de septiembre de 2001}

Ahora bien, si estos dos casos sirven para constatar el carácter tradicionalmente más abierto y garantista del Tribunal Supremo de EE UU, podemos sostener que tras los atentados de las torres gemelas de 2001, dicho órgano judicial ha dejado de ser más garantista que las jurisdicciones europeas en la medida en que no se ha enfrentado abiertamente con la política antiterrorista de la Administración Bush, que como se ha visto, es más severa que la europea.

Efectivamente, ante la política legislativa que han seguido los diversos Estados ante el terrorismo, los Tribunales de algunos de esos países han reaccionado ejerciendo el control de constitucionalidad de esas medidas y en otros casos aplicando los preceptos penales bajo la salvaguarda de un proceso pleno de garantías.

Especial relevancia tienen las Sentencias del Tribunal Supremo de Estados Unidos que se dictaron el 28 de junio de $2004^{34}$ en relación a los casos Rasul v. Bush $^{35}$ [124 S. Ct. 2686 (2004)], al caso Hamdi v. Rumsfeld ${ }^{36}$ [124 S. Ct.

${ }^{34}$ Un buen comentario de estas sentencias, que en buena medida seguimos, en Benazzo, Antonella, L'emergenza nel conflicto fra libertà e sicurezza, G. Giapichelli Editore - Torino, 2004, pp. 172 y ss.

${ }_{35}$ Para una buena síntesis, acompañada de consideraciones críticas, Dworkin, Ronald, «Corte Suprema e garanzie nel trattamento dei terrorista», Quaderni costituzionali, año XXV, número 4, diciembre 2005, pp. 912 y ss. [Traducción del artículo «What the Court Teally Said», publicado en The New York Review of Books, vol. 51, n. ${ }^{\circ} 13$ (12 de agosto 2004, traducido al italiano por Stefania Zolotti).

36 Sintetizando el resumen que ofrece Dworkin, Ronald, «Corte Suprema e garanzie nel trattamento dei terrorista», Quaderni costituzionali, año XXV, número 4, diciembre 2005, pp. 906 y ss. [Traducción del artículo "What the Court Teally Said», publicado en The New York Review of Books, vol. 51, n. ${ }^{\circ} 13$ (12 de agosto 2004, traducido al italiano por Stefania Zolotti), cabe señalar:

Yasir Esam Hamdi es un ciudadano americano de 24 años, nacido en Louisiana, crecido en Arabia Saudi y capturado en 2001 en Afganistán por fuerzas de la Alianza Afgana del Norte, en lucha contra los talibanes. Fue entregado al ejército americano. El Gobierno de EE UU lo envió a la bahía de Guantánamo, pero a continuación, una vez descubierta su nacionalidad estadounidense, lo transfirió primero a una cárcel militar de Virginia y luego a una nave prisión en Carolina del Sur donde, durante más de dos años, fue mantenido en una situación de absoluto aislamiento y, durante una gran parte del periodo de tiempo, sin posibilidad de entrar en contacto con un abogado.

En junio de 2002 el padre presentó por su cuenta una solicitud de habeas corpus —esto es, una solicitud ante los tribunales con la que se solicitaba que sus carceleros justificaran ante un Tribunal el hecho de que venían manteniendo detenida a una persona- sosteniendo que Hamdi no combatía al lado de los talibanes — como sostenía el Gobierno de EE UU— sino que se encontraba en Afganistán como voluntario para proporcionar ayuda humanitaria. El ejército respondió 
con un memorandum de nueve párrafos firmado por Michael Mobbs, funcionario del Departamento de defensa, del cual resultaba, aunque no se proporcionaban pruebas, que Hamdi se encontraba con una unidad de talibanes y que en el momento en que la misma se rindió a la Alianza, fue capturado estando en posesión de un fusil Kalashnikov. Los abogados del padre presentaron en consecuencia una nueva solicitud instando o la definitiva puesta en libertad de su hijo o la presentación de elementos sustanciales y detallados que apoyaran el memorandum de Mobbs.

Un Tribunal de Distrito Federal de Virginia reconoció que el memorandum era, considerado en sí mismo, insuficiente para justificar el tratamiento dispensado a Hamdi. Ordenó al Gobierno elaborar datos más detallados, en línea con los que serían necesarios en un proceso penal ordinario.

Pero el Tribunal Federal de Apelación del Cuarto Circuito reformó la Sentencia del Tribunal de Distrito, afirmando que el Presidente, como comandante supremo, tiene el poder constitucional de declarar combatiente enemigo a cualquier persona capturada en cualquier contexto de operaciones militares y que ningún tribunal tiene facultades para discutir la calificación del Presidente.

El Tribunal Supremo anuló la resolución del Cuarto Circuito y reenvió el asunto al Tribunal de Distrito para que continuara en la línea de su decisión precedente. La magistrado Sandra Day O'Connor formuló una opinión a la que se añadieron otros tres jueces —el Presidente del Tribunal, William Rehnquist, y los magistrados Anthony Kennedy y Stephen Breyer- y que representa la mayoría relativa y en consecuencia la opinión dominante en el caso.

La ley Federal prevé que «ningún ciudadano puede ser privado de libertad en prisión o detenido de cualquier otra manera por EE UU sino de conformidad con un acto del Congreso». Pero la magistrado O'Connor sostiene que la ley de autorización para el uso de la fuerza militar que el Congreso había aprobado tras el 11 de septiembre de 2001, permitiendo al Presidente perseguir a Al-Qaeda y a los que la apoyaran, por clara implicación le había concedido también el poder de detener a miembros de la fuerzas enemigas capturados en combate. Las leyes de la guerra, reconocidas ampliamente por el derecho norteamericano e internacional y fruto de una larguísima tradición —dice la magistrada O'Connor- prevén el específico poder de detener hasta el fin de las hostilidades a los miembros de las fuerzas enemigas capturados. En su opinión, es evidente que el Congreso reconocía al Presidente tal poder precisamente para evitar que los enemigos capturados pudieran volverse a reunir con los restantes retomando así el combate.

La cuestión suscitada ante el Tribunal, subraya la opinión mayoritaria, tenía por tanto naturaleza constitucional: no se trataba tanto de dilucidar si el Congreso había autorizado al Presidente a detener enemigos combatientes, sino si el ejercicio por parte del propio Presidente del poder de detener ciudadanos americanos sin un serio examen judicial viola la V Enmienda de la Constitución, que establece que nadie puede ser privado de libertad sin un "proceso justo». El problema constitucional se puede resolver, según el criterio de la magistrado O’Connor sólo ponderando por una parte el grave perjuicio que se irrogaría a la persona ingresada en prisión de manera errónea y genérica y por otra el riesgo de la seguridad nacional y las cargas que recaerían en las fuerzas militares si se permite a los prisioneros revindicar un preexamen judicial de la propia detención. Para la magistrado O'Connor el Tribunal de Distrito de Virginia había concedido al recurrente una excesiva protección a un precio demasiado alto para la seguridad colectiva, al considerar que Hamdi podía ser arrestado solamente si, sobre la base de los mismos parámetros de fundamentación exigidos en un procedimiento penal ordinario, se probara su condición de enemigo combatiente. Por otra parte, el Cuarto Circuito por su parte había reconocido una protección demasiado exigua al sostener que no se puede revisar la afirmación del Presidente según la cual Hamdi, habiendo sido capturado en un teatro de operaciones militares, era efectivamente un combatiente enemigo. 
Un equilibrio equitativo en su opinión exigiría que «un ciudadano detenido que intente oponerse a la calificación de combatiente enemigo que se le haya dispensado deba recibir información acerca de los fundamentos efectivos que determinan tal identificación suya, además de la legítima oportunidad de impugnar ante un órgano de decisión imparcial las pruebas fácticas aportadas por el Gobierno".

Hamdi, continúa la magistrada, tiene el pleno derecho de recibir asistencia legal en relación con cualquier otro procedimiento. Considera la magistrada que el único fin legítimo de la detención sin proceso equitativo consiste en evitar que un soldado enemigo continúe combatiendo. Esto, dice Dworkin, parece dejar entender dos cosas, que al término de las hostilidades el ciudadano no puede continuar detenido y que no puede ser interrogado.

Pero las sugerencias más detalladas de la magistrada O’Connor minan la protección que las anteriores afirmaciones generales y abstractas parecen reconocer. El Tribunal imparcial al que los detenidos deberían poder apelar — añade la magistrada — no tiene que ser necesariamente un tribunal ordinario, sino que podría también tratarse de una Comisión militar «autorizada ad hoc y oportunamente constituida». Las reglas probatorias de tal tribunal — continua la magistrada O’Connor- para el Gobierno podrían ser mucho más favorables que las utilizadas en los tribunales militares ordinarios. En particular, podría admitirse incluso los testimonios de referencia; el propio testimonio contenido en el memorandum de Mobbs — que considera la magistrado que es apenas un borrador - podría en sí ya considerarse suficiente.

La magistrado O'Connor precisa luego que la carga de la prueba podría ser invertida, de modo que a un detenido se le podría exigir demostrar que él no es un enemigo combatiente, en lugar de hacer recaer en el Gobierno tal carga de la prueba.

Señala Dworkin que ni siquiera las reglas propuestas por el Departamento de Defensa para los tribunales militares, que decidirán respecto de algunos sujetos detenidos por delitos de guerra en Guantánamo, - tribunales que han sido denunciados como inicuos por los abogados defensores y por asociaciones de derechos humanos - imponen al imputado la carga de demostrar su propia inocencia.

La Sentencia del caso Hamdi sitúa al prisionero en una situación muy gravosa. Es cierto que la opinión mayoritaria exige al Gobierno revelar sus pruebas tanto a Hamdi como a sus abogados, y que permite a Hamdi recurrir las afirmaciones del Gobierno. Pero en caso de que el Gobierno no añadiera nada a lo ya contenido en el memorandum Mobbs, como quiera que le corresponde a Hamdi demostrar lo infundado del referido memorandum, sus oportunidades resultan muy limitadas. Si hubiera testigos que pudieran demostrar su captura por parte de la Alianza del Norte podría convencerles de que declararan a la Comisión militar intentando persuadir a ésta de que él decía la verdad y no el memorandum. A falta de esos testigos, ironiza Dworkin, se vería obligado a buscar en medio del desierto afgano a un «señor de la guerra» dispuesto a presentarse para testificar y para participar en un careo.

De todas formas, sostiene la magistrada O'Connor, Hamdi debería ser liberado al final de los combates en los que está acusado de haber participado. Pero subraya que también los combates y las correspondientes acciones militares continúan en diversas zonas de Afganistán y que el gobierno, desde su propio punto de vista podría pensar en retener a Hamdi hasta que considere haber ganado la "guerra contra el terrorismo», toda vez que Hamdi dejó Arabia Saudita precisamente para combatir a favor del Islam. Probablemente la magistrado tiene razón cuando señala que sería injustamente gravoso pretender que las fuerzas militares redactaran dossieres detallados y motivados para todo prisionero capturado. Pero tal razonamiento, dirigido a proteger a los militares, lo hace a consta de la protección a los detenidos. 


\section{3 (2004)] y al caso Rumsfeld v. Padilla ${ }^{37}$ [124 S. Ct. 2711 (2004)], y sobre todo la Sentencia Hamdan v. Rumsfeld, de 28 de marzo de 2006. Las primeras}

${ }^{37}$ Resumiendo la síntesis de Dworkin, Ronald, «Corte Suprema e garanzie nel trattamento dei terrorista", Quaderni costituzionali, año XXV, número 4, diciembre 2005, págs. 910 ss. [Traducción del artículo "What the Court Teally Said", publicado en The New York Review of Books, vol. 51, n. 13 (12 de agosto 2004, traducido al italiano por Stefania Zolotti):

José Padilla es un ciudadano americano, nacido en Brooklin, que se convirtió a la religión islámica. Ronald Dworkin recuerda en su síntesis de la Sentencia del Tribunal Supremo que el Fiscal General sustituto de EE UU, James Comey, mientras el Tribunal Supremo estaba decidiendo sobre el caso Padilla, convocó una conferencia de prensa durante la cual acusó a Padilla de tener fuertes lazos con Al-Qaeda. En su opinión, Padilla había concebido un plan para hacer explotar una «bomba sucia» radioactiva en EE UU, pero Al-Qaeda se opuso, proponiéndole en cambio hacer explotar unos edificios utilizando gas natural. Pero el propio Fiscal reconoció que su convicción no se basaba en pruebas que hubieran sido válidas ante un Tribunal.

Entrando en los antecedentes del caso, cabe destacar que después de cuatro años pasados en oriente medio, Padilla volvió a Chicago, donde fue arrestado por orden federal en calidad de testigo material para las investigaciones relativas al 11 de septiembre de 2001. Padilla fue luego transferido a una cárcel en Nueva York. Su abogado neoyorquino nombrado por el Tribunal impugnó el arresto ante un Tribunal de Distrito Federal de Nueva York, después de que el Gobierno retirara la instancia con la que lo consideraba testigo material, declarándolo combatiente enemigo y procediendo a transferirlo a una base militar en Carolina del Sur, donde fue retenido durante más de dos años en total aislamiento, sometido a interrogatorios continuos y sin posibilidad de comunicar con un abogado durante la mayor parte del tiempo.

Inmediatamente después de que Padilla fuera transferido allí, su abogado presentó una solicitud de habeas corpus al Tribunal Federal de Nueva York. Dicho Tribunal la rechazó, sosteniendo que el Presidente y sus altos funcionarios no estaban obligados en absoluto a justificar ante un tribunal sus propias condiciones respecto de una persona capturada y considerada combatiente enemigo. El Segundo Tribunal de Distrito de Apelación de Nueva York le dio la vuelta a tal decisión, sosteniendo que el Gobierno no tenía poder para mantener detenido a Padilla sin acusarlo de ningún delito. El Gobierno recurrió al Tribunal Supremo.

El Tribunal Supremo se dividió en cinco contra cuatro. Rehnquist, en una opinión a la que se añadieron los magistrados Antonin Scalia, O’Connor, Kennedy y Clarence Thomas, desautorizó lo decidido por el Segundo Circuito. Considera que el abogado de Padilla había planteado el asunto en una sede equivocada. En su opinión, la ley federal de habeas corpus exige que los detenidos en el territorio de EE UU citen a juicio a los que los tienen directamente bajo su custodia —en el caso de Padilla, Melanie A. Marr, comandante de la brigada naval en que se encontraba- y no a cualquier otro oficial superior, como era por ejemplo el Secretario de Defensa (que era contra el que se había dirigido la demanda) y que dichas personas deben ser citadas en el distrito federal de custodia, en aquel caso, Carolina del Sur.

Rehnquist hace referencia a precedentes con antigüedad de un siglo del propio Tribunal Supremo de los que se desprende que en un procedimiento de habeas corpus el demandado necesario ha de ser en realidad «el carcelero» o la persona que tenga la custodia directa de la parte detenida y por otra parte que la acción judicial debe sustanciarse donde se encuentre el propio carcelero. Aunque reconoce que el Tribunal Supremo, en el pasado, había elaborado diversas excepciones a tal regla las analiza detalladamente para demostrar que ninguna era aplicable al caso en cuestión. 
tres decisiones del Tribunal Supremo, largamente esperadas, se produjeron el 28 de junio de 2004, y fueron recibidas por los medios de comunicación como una significativa derrota para la administración y una importante victoria de los derechos civiles y humanos. Es significativo que la supuesta desautorización de la

El Tribunal en consecuencia rechaza el recurso, basándose precisamente en el elemento procesal, imponiendo a Padilla recomenzar por el principio del camino en Carolina del Sur.

El magistrado John Paul Stevens presentó un elocuente opinión discrepante, al que se adhirieron los magistrados David Souter, Ruth Ginsbur y Breyer, con el que discute la opción del Tribunal de resolver un caso que "plantea cuestiones de extrema importancia para la Nación» por medio de una "servil aplicación» de una regla procesal. La cuestión pertinente, según estos magistrados, no es tanto si alguna de las excepciones examinadas se aplican a la regla procesal, sino si los principios subyacentes a la regla, desde la perspectiva de los cuales tales excepciones habían sido reconocidas, requieren además una nueva excepción para ser aplicados en el caso en cuestión.

La ratio de la regla procedimental es que hace falta disuadir del «forum shopping», esto es, de la posibilidad, por parte del prisionero, de elegir el tribunal en que se encuentran los jueces que considere más benévolos respecto de él. Muchas de aquellas excepciones se habían establecido precisamente para evitar que el Gobierno utilizase la misma táctica. En un caso determinado, por ejemplo, una vez que el prisionero había intentado tramitar la causa en una determinada jurisdicción, el gobierno lo transifiró a otra. El Tribunal sostuvo que, en tales circustancias, se debía autorizar la continuación del juicio en la sede originaria. Stevens observa que también en el caso de Padilla hubiera convenido una análoga excepción para el mismo fin. En este caso, el Gobierno había comenzado el proceso contra Padilla en Nueva York y lo había transferido a Carolina del Sur solamente una vez que un Tribunal de Nueva York se había pronunciado ya respecto de su solicitud de ser liberado. Es irrelevante que el Gobierno haya cambiado las razones en las que había basado la detención: si el Gobierno lo hubiera avisado del cambio, su representante legal se hubiera opuesto formulando su oposición en Nueva York, antes de que fuera transferido.

Dice Dworkin que sería un grave error creer que esta decisión del Tribunal tiene solamente un impacto procesal y no sustancial. Si el Gobierno puede elegir el Tribunal en el que defender la causa enviando a la prisión correspondiente a los detenidos políticos, puede también esperarse que aumenten las posibilidades de convencer a los tribunales inferiores de que interpreten en beneficio del Gobierno los parámetros genéricos de la sentencia Hamdi y a sostener que un detenido no ha conseguido levantar la carga de la prueba impuesta por la misma.

Observa Dworkin que si tenemos en cuenta que el Tribunal, en la tercera de las sentencias de 2004 relativas a la detención, había decidido que los prisioneros detenidos en el campo militar de la bahía de Guantánamo podrían presentar una solicitud de habeas corpus en un tribunal federal americano, es previsible que el gobierno no conduzca más prisioneros a aquel campo. Incluso alguno periódico de EEUU ha publicado que el Gobierno se había planteado transferir a las personas ya detenidas en Guantánamo y que no tiene intención de dejar en libertad pronto, en Carolina del Sur o en cualquier otro distinto «conservador» de manera que, hubiera sido más correcto que el Tribunal Supremo hubiera vigilado precisamente el «forum shopping "por parte del Gobierno y no por parte de los detenidos. El Tribunal hubiera podido hacerlo resolviendo que cuando las detenciones son ordenadas por el Presidente o por otro funcionario federal, el propio Presidente o el funcionario federal en cuestión han de ser los demandados a citar en el procedimiento de habeas corpus y que el distrito de Columbia sea la sede competente. 
actuación de la Administración procediera de un Tribunal Supremo que podía considerarse excepcionalmente conservador. En efecto ${ }^{38}$, el Tribunal era presidido por William Rehnquist, nombrado por el Presidente Reagan en 1986 y estaba compuesto por jueces designados mayoritariamente por Presidentes republicanos: Sandra O'Connor, Antonin Scalia, Anthony Kennedy, David Souter, Clarence Thomas y John Stevens. Sólo dos jueces, Ruth Ginsdburg y Stephen Breyer habían sido nombrados por el Presidente Clinton. A pesar de ello el Tribunal prácticamente se dividió en dos en cada uno de los tres casos examinados.

Pero acaso los comentaristas hayan exagerado al valorar el impacto concreto de tales decisiones, como ya señaló Ronald Dworkin ${ }^{39}$ en un temprano comentario a estas rtes sentencias.

Es cierto que el Tribunal ha señalado que, incluso en guerra, cualquier forma de detención de sospechosos combatientes enemigos debe estar sujeta a alguna forma de revisión por parte de Tribunales imparciales, pero también es cierto que él mismo sugiere al respecto reglas procesales que omiten importantes formas tradicionales de protección para las personas acusadas de delitos. El Gobierno ha podido con cierta facilidad satisfacer los indulgentes criterios procesales establecidos por el Tribunal Supremo, al menos en las tres primeras sentencias que dictó el 28 de junio de 2004, sin alterar sustancialmente su política en la lucha contra el terrorismo.

De las tres Sentencias de 2004, acaso la más importante fuera la del caso $R a-$ $s u l^{40}$. Un grupo de detenidos en Guantánamo solicitó un writ of habeas corpus,

38 Benazzo, Antonella, L'emergenza nel conflicto fra libertà e sicurezza, G. giappichelli Editore, Torino, 2004, pp. 172 y ss.

39 Dworkin, Ronald, "Corte Suprema e garanzie nel trattamento dei terrorista», Quaderni costituzionali, año XXV, número 4, diciembre 2005, pp. 915 y ss. [Traducción del artículo «What the Court Teally Said», publicado en The New York Review of Books, vol. 51, n. ${ }^{\circ} 13$ (12 de agosto 2004, traducido al italiano por Stefania Zolotti).

40 Siguiendo la síntesis que ofrece Dworkin, Ronald, «Corte Suprema e garanzie nel trattamento dei terrorista", Quaderni costituzionali, año XXV, número 4, diciembre 2005, pp. 915 y ss. [Traducción del artículo "What the Court Teally Said», publicado en The New York Review of Books, vol. 51, n. ${ }^{\circ} 13$ (12 de agosto 2004, traducido al italiano por Stefania Zolotti):

La Ley federal sobre habeas corpus prevé que los Tribunales de distritos federales tienen el poder de entender de solicitudes «dentro de sus respectivas competencias» [28 USC 2241(a), 9(c) 3.]. La administración Bush creó la conocida prisión en la Bahía de Guantánamo, en Cuba, precisamente basada en la idea de que tal disposición excluía acciones de habeas corpus por parte de los prisioneros allí detenidos toda vez que Estados Unidos no es soberano en el mencionado territorio, por lo que no estaría sujeto a la jurisdicción de un Tribunal Federal. No obstante, dos ciudadanos australianos y doce cubaitíes de los alrededor de seiscientos detenidos en Guantánamo presentaron solicitudes de habeas corpus ante el Tribunal Federal del distrito de Columbia, solicitando que cesara el arresto, que se les permitiera el acceso a un abogado, que no se procediera a inte- 
rrogatorios y otras garantías (dos de los detenidos, británicos, uno de los cuales era Shafiq Rasul, inicialmente entre los actores, fueron pronto dejados en libertad y volvieron a su país).

El juez Stevens, junto con los magistrados O’Connor, Kennedy, Souter, Ginsburg y Breyer, consideraron que con la expresión «respectivas competencias» se entendía no la jurisdicción del lugar en que estuvieran detenidos los prisioneros, sino aquella en que se encontraran los funcionarios responsables de la detención; además, sostuvieron que cuando el Gobierno mantiene privados de libertad a prisioneros en un territorio extranjero bajo su efectivo y constante control pero sin que tales actos sean de jurisdicción de un Tribunal Federal, se puede presentar una solicitud de habeas corpus ante un Tribunal Federal de Estados Unidos que tenga jurisdicción sobre el Presidente. El Gobierno se había basado en la sentencia del Tribunal Supremo en el caso Jonson v. Eisentrager de 1950, con la que se había sostenido que no tenían ningún derecho constitucional de presentar acciones de habeas corpus ante un Tribunal americano los ciudadanos alemanes capturados en China durante la Segunda Guerra Mundial, considerados culpables de crímenes de guerra por una Comisión militar estadounidense en Nanking, y luego hechos prisioneros en la cárcel de Landsberg en la Alemania ocupada. Stevens observa que la «jurisdicción y el control» de Estados Unidos en la Bahía de Guantánamo se basan en un contrato de arrendamiento permanente, estipulado por Cuba hace mucho tiempo. Subraya que el caso Eisentrager se había basado en ideas relativas a la Ley sobre habeas corpus que habían sido superadas o desautorizadas por posteriores decisiones del Tribunal Supremo y no encontraron por ello aplicación para los detenidos de Guantánamo. En un voto particular concurrente, Kennedy ofrece una argumentación distinta fundada no tanto en la distinción entre el caso Eisentrager y el caso en cuestión, sino más bien en la aplicación de aquella sentencia que, según él, estableció una escala gradual para determinar, en los Tribunales americanos, los derechos de los prisioneros extranjeros mantenidos como tales en el extranjero. No tienen ningún derecho los extranjeros considerados nacionales de un poder enemigo por un Tribunal, como era el ejemplo de los prisioneros alemanes, mientras que los detenidos de Guantánamo, que podrían incluir "tanto amigos como enemigos», no podrían ser mantenidos en esa situación, sin proceso u otras garantías procesales. En consecuencia, seis magistrados consideraron que los detenidos sin ciudadanía pueden valerse de la solicitud de habeas corpus ante Tribunales federales desde el momento en que se encuentran en áreas sometidas al efectivo y constante control estadounidense, como ocurre en Guantánamo.

En un voto discrepante punzante, Scalia, en su propio nombre, y en el de Rehnquist y de Thomas, observa que el Tribunal estaba invalidando la decisión Eisentrager, lo que perjudicaba seriamente al Gobierno que había confiado en ella para trasladar sus prisioneros a Guantánamo. Advierte que la decisión del Tribunal podría tener consecuencias desastrosas. Según Scalia, el análisis de Stevens significa que los prisioneros militares americanos, pero no solo los detenidos en Guantánamo, sino los que se hallen en cualquier lugar del mundo bajo control de Estados Unidos — por ejemplo en Irak - podrían demandar al propio Gobierno ante los Tribunales americanos. "Como "jurisdicción y control" obtenidos por medio de un contrato de arrendamiento de hecho no difieren de "jurisdicción y control" adquiridos con el uso legal de las armas, algunas zonas de Afganistán y de Irak deberían considerarse sometidas a nuestras leyes nacionales».

Analizadas conjuntamente, como ya señaló Dworkin, estas tres decisiones tendrían un fuerte impacto en las políticas de detención de la administración Bush, aunque dicho impacto, a pesar de las consideraciones de Scalia, también podía ser muy reducido. Hamdi y Padilla pueden continuar con su intento de oponerse a su propia detención gracias al apoyo de los abogados, pero tendrán mucha dificultad para levantar la carga de la prueba. El Pentágono, evidentemente preocupado por prevenir una oleada de solicitudes de habeas corpus a favor de los detenidos de Guan- 
reclamando el derecho de comunicarse con sus abogados y el acceso a un tribunal imparcial. El asunto que se le planteaba al Tribunal era saber si los extranjeros detenidos fuera del territorio de Estados Unidos pueden acudir a los tribunales americanos para hacer valer derechos invocando la constitución de Estados Unidos. El Tribunal Supremo de EE UU falló el 28 de junio de 2004, en la Sentencia conocida como Rasul v. Bush, a favor de los recurrentes y les reconoció el derecho a acudir a los tribunales ordinarios. Esta Sentencia tuvo una gran importancia: los tribunales podrían revisar la legalidad de la orden de noviembre de 2001, que era el instrumento jurídico esencial elaborado por la administración para fijar dicho estatuto.

Pero para evitar que los detenidos de Guantánamo inundaran de recursos los tribunales estadounidenses, Bush presentó al Congreso un proyecto de ley que el 30 de diciembre de 2005 se convirtió en la Ley de Tratamiento de los Detenidos, en la que se declaraba que los presos de Guantánamo sólo tenían derecho a presentar sus casos de habeas corpus ante un concreto tribunal, el Tribunal de apelaciones del distrito de Columbia.

Habría que esperar a la Sentencia Hamdan, de 28 de marzo de $2006^{41}$, para que el Tribunal Supremo decidiera que, frente a la postura de la Administración

tánamo, anunció inmediatamente la creación de un Tribunal para la revisión del status de los combatientes, compuesto por militares, al que podrían dirigirse los detenidos para discutir su calificación como combatientes enemigos. Se les concedería el auxilio de "representantes personales» asignados por el Gobierno, pero no se les permitiría asistencia por parte de abogados, y habrían de contrarrestar una "presunción a favor de las pruebas presentadas por el Gobierno». No obstante la afirmación de la magistrado O’Connor, con base en la cual Hamdi gozaría del derecho a acudir a ayuda legal en todos los posteriores procedimientos relativos a su caso, el comunicado del Pentágono informaba que estos robos tribunales respondían a todos los requisitos que el Tribunal Supremo había impuesto.

${ }^{41}$ Sentencia del Tribunal Supremo en el caso Hamdan, 548 US Hamdan v. Rumsfeld 2006. La Sentencia aparece acompañada de tres opiniones disidentes, de los jueces Thomas, Alito y Scalia, y por dos opiniones más, la Concurring Opinion del juez Breyer, y la Concurring in part del juez Kennedy. El texto de la Sentencia puede encontrarse en la siguiente dirección: http://www. supremecourtus.gov/opinions/05pdf/05184.pdf\#search=\%22hamdan\%20v.\%20rumsfeld\%20 appeals\%20court\%22. Una intersante crítica de la Sentencia en Bollo Arocena, M. ${ }^{a}$ Dolores, «Hamdan v. Rumsfeld. Comentario a la Sentencia dictada por el Tribunal Ssupremo de Estados Unidos el 29 de junio de 2006», Revista Electrónica de Estudios Internacionales, 12, 2006 (www.reei.org), quien resume la problemática que en ella se plantea, así:

Las circunstancias en las que resultaron detenidos los centenares de individuos que han pasado por Guantánamo, mucho de los cuales permanecen en la base a día de hoy, son variadas: algunos de ellos fueron hechos prisioneros en el contexto de los conflictos armados que estaban y están teniendo lugar en países como Afganistán e Iraq; otros, sin embargo, fueron capturados en el marco de lo que se conoce como guerra contra el terrorismo, en lugares tan dispares y tan alejados de sendas contiendas bélicas como Tailandia, Bosnia Herzegovina o Zambia. 
Bush, las Convenciones de Ginebra son aplicables, al menos en parte, a los prisioneros de Guantánamo ${ }^{42}$.

Como hemos señalado anteriormente, un preso llamado Hamdan, que había sido chófer y guardaespaldas de Osama ben Laden, había planteado una petición de habeas corpus que discutía la legalidad de las comisiones militares con las que Bush quería juzgar a los detenidos en la base antillana y que habían sido autorizadas por la orden militar de noviembre de 2001. Después de pasar por dos tribunales inferiores, el 29 de junio de 2006, el Tribunal Supremo dictó sentencia, la conocida como Hamdan v. Rumsfeld, que declaró que tales comisiones eran ilegales por ser contrarias al Código de Justicia Militar y al común artículo 3 de las Convenciones de Ginebra. Esto significaba declarar la ilegalidad de buena parte del contenido de la orden militar de noviembre de 2001.

El caso de Hamdan, nacional yemení protagonista de la Sentencia a la que ahora nos referimos, nos sitúa en el estudio del derecho aplicable y el tribunal competente para enjuiciar a un individuo detenido en el contexto de un conflicto armado —el conflicto afgano- - y colocado bajo la jurisdicción de Estados Unidos por su presunta condición de miembro del grupo terrorista $\mathrm{Al}$ Qaeda. Salim Ahmed Hamdan fue detenido en noviembre de 2001 por la milicia e inmediatamente entregado a las fuerzas de Estados Unidos, aunque su traslado a la prisión de Guantánamo no tuvo lugar hasta el mes de junio de 2002.

El sr. Hamdan había defendido en el curso de los distintos procesos celebrados ante la justicia de Estados Unidos que se encontraba amparado por los Convenios de Ginebra de 1949 y que gozaba del derecho a ser enjuiciado por un tribunal militar de Estados Unidos, y no por una comisión militar, creada ilegalmente y absolutamente irrespetuosa con algunos derechos procesales elementales. Por su parte, el Gobierno del Sr. Bush negaba de manera insistente que los Convenios de Ginebra en su integridad o el art. 3 común, en solitario, fueran aplicables a un presunto miembro del grupo terrorista Al Qaeda, esgrimiendo, además, que aunque lo fueran, no generarían el derecho a invocarlos judicialmente por un particular. Por lo demás, la posición oficial de las autoridades estadounidenses ha consistido en defender la legalidad de las comisiones militares.

En la Sentencia dictada por el Tribunal Supremo el 29 de junio en el caso Hamdan, cabe destacar dos aspectos concretos: en primer lugar, el marco jurídico aplicable a los miembros del grupo terrorista Al Qaeda capturados en Afganistán y confinados en la prisión de Guantánamo. Y, en segundo lugar, la cuestiones de legalidad ligadas a la creación de comisiones militares para enjuiciar a los individuos detenidos en Guantánamo, en este caso a Hamdan, por suponer en algunos aspectos, una violación del derecho interno de Estados Unidos y del derecho internacional humanitario.

42 Acerca de esta cuestión, cfr. Pérez González, M., Rodríguez Villasante y Prieto, J. L., «El caso de los detenidos de Guantánamo ante el Derecho Internacional Humanitario y de los Derechos Humanos», REDI, 2002-I, Vol. LIV, pp. 11-39, p. 18. En el mismo sentido, Abril, R., «De Guantánamo a Bagdad. Estatuto jurídico y trato a los detenidos en la lucha contra el terrorismo'», REEI, n. ${ }^{\circ}$ 9, 2005, pp. 1-33. Cfr. Pérez González, M., Rodríguez Villasante y Prieto, J.L., «El caso de los detenidos de Guantánamo ante el Derecho Internacional Humanitario y de los Derechos Humanos», REDI, 2002-I, Vol. LIV, pp. 11-39, p. 18. En el mismo sentido, Abril, R., «De Guantánamo a Bagdad. Estatuto jurídico y trato a los detenidos en la lucha contra el terrorismo'", REEI, n. ${ }^{\circ}$ 9, 2005, pp. 1-33. 
Para superar esta ilegalidad es para lo que se promulgaría la Ley de Comisiones Militares, que básicamente tiene por objeto convertir en ley en 2006 lo que en 2001 no era más que una orden del Presidente.

El Tribunal, no se conformó con declarar la ilegalidad de las comisiones por no atenerse a las exigencias del Código de Justicia Militar, sino que además las declaró contrarias al común artículo 3 de las Convenciones de Ginebra. Esta afirmación ha tenido más calado, pero sólo a primera vista. En efecto, ha servido para que se interpretara que por fin el Tribunal Supremo había obligado a Bush a reconocer la aplicabilidad de las Convenciones de Ginebra a los presos de Guantánamo. Pero la realidad es exactamente la contraria. El común artículo 3 de las Convenciones de Ginebra ${ }^{43}$ es un precepto en el que se señalan unas mínimas normas a respetar en los conflictos civiles en los que no es aplicable el resto de las Convenciones. Dicho de otro modo: decir que se aplica el común artículo 3 equivale a reconocer que no se aplica nada del resto. Lo que hace el Tribunal es interpretar que, en la medida en que este artículo 3 fija unos mínimos de humanitarismo para una determinada clase de conflictos donde no rige el resto de las Convenciones, debe aplicarse a todos aquellos en los que, por lo que sea, Ginebra no sea aplicable. Por lo tanto, decir que el Tribunal Supremo ha condenado a Bush a respetar las Convenciones de Ginebra es una generalización que desorienta respecto de lo que realmente ha decidido el Tribunal Supremo.

43 Concretamente dice el común artículo 3: «En caso de conflicto armado que no sea de índole internacional y que surja en el territorio de una de las Altas Partes Contratantes, cada una de las Partes en conflicto tendrá la obligación de aplicar, como mínimo, las siguientes disposiciones: 1) Las personas que no participen directamente en las hostilidades, incluidos los miembros de las fuerzas armadas que hayan depuesto las armas y las personas puestas fuera de combate por enfermedad, herida, detención o por cualquier otra causa, serán, en todas las circunstancias, tratadas con humanidad, sin distinción alguna de índole desfavorable, basada en la raza, el color, la religión o la creencia, el sexo, el nacimiento o la fortuna, o cualquier otro criterio análogo. A este respecto, se prohíben, en cualquier tiempo y lugar, por lo que atañe a las personas arriba mencionadas: a) los atentados contra la vida y la integridad corporal, especial-mente el homicidio en todas sus formas, las mutilaciones, los tratos crueles, la tortura y los suplicios; b) la toma de rehenes; c) los atentados contra la dignidad personal, especialmente los tratos humillantes y degradantes; d) las condenas dictadas y las ejecuciones sin previo juicio ante un tribunal legítimamente constituido, con garantías judiciales reconocidas como indispensables por los pueblos civilizados. 2) Los heridos y los enfermos serán recogidos y asistidos. Un organismo humanitario imparcial, tal como el Comité Internacional de la Cruz Roja, podrá ofrecer sus servicios a las Partes en conflicto. Además, las Partes en conflicto harán lo posible por poner en vigor, mediante acuerdos especiales, la totalidad o parte de las otras disposiciones del presente Convenio. La aplicación de las anteriores disposiciones no surtirá efectos sobre el estatuto jurídico de las Partes en conflicto». 


\subsection{Algunos tribunales europeos}

\subsubsection{El Tribunal Constitucional Federal alemán el 3 de marzo de $2004^{44}$ declaró inconstitucional una modificación de la Ordenanza Procesal Penal que}

44 1. La resolución fue dictada en relación con varios recursos de amparo dirigidos contra determinadas disposiciones del Código de Procedimiento Penal alemán que permitían la gravación de conversaciones de personas que se encontraban en su domicilio o en lugares asimilables.

La decisión se divide en dos partes: a) reflexión acerca de la constitucionalidad del art. 13.3 LF de Bonn, es decir la constitucionalidad del texto reformado del art. 10 que fue completado por reglas que permitían este tipo de «control acústico»; y b) aplicación de los principios formulados en la parte a) a las disposiciones concretas del Código de Procedimiento Penal.

a) El art. 13.3 LF Bonn es interpretado por el TCF alemán a la luz del art. 1, la garantía de la dignidad humana, valor central en la Ley Fundamental de Bonn, y su alcance fue restringido por eso.

b) La mayor parte de las disposiciones atacadas del Código de Procedimiento Penal fue declarada inconstitucional.

Se debe señalar en este contexto que el art. 1.1 Ley Fundamental de Bonn garantíza la dignidad humana y constituye una unidad funcional con el derecho al libre desarrollo de la personalidad reconocido en el art. 2.1 de la misma LF. Este último derecho fundamental es extendido por la jurisprudencia constitucional alemana y concebido como un derecho general a la libertad de acción, el derecho fundamental «madre» de la libertad, subsidiario respecto a los derechos específicos de libertad.

Para el Tribunal la inviolabilidad del domicilio es expresión concreta de la dignidad humana. Esta se manifiesta con particular relevancia en la protección de los derechos relacionados con el desarrollo de la personalidad. La protección de la esfera privada en el ámbito físico o territorial está para el Tribunal estrechamente conectada con dicha garantía. La conclusión a la que llega el TCF es que, por su dimensión, las conversaciones privadas desarrolladas en el propio domicilio no deben ser investigadas porque están protegidas por la dignidad humana, la esfera privada que se desarrolla en el domicilio o lugar en que se habita debe ser absolutamente protegida. No es posible una ponderación con otros valores, ni siquiera con valores de rango constitucional. En particular, no es posible la relativización de esta protección por la concurrencia de intereses públicos, Por importantes que sean tales intereses. La protección es absoluta a este respecto. Solamente cuando se trate de una conversación no privada, así por ejemplo de una conversación sobre el delito cometido o con una persona involucrada en el delito cometido, puede considerarse constitucional la investigación acústica clandestina en lugares donde se habita. De esta manera, hay una distinción estricta entre conversación privada y no privada.

Para observar este límite es indispensable crear un procedimiento adecuado. El TCF subraya que está prohibida la investigación si es probable que la conversación sea de naturaleza privada y que la investigación debe ser interrumpida si se revela, en el curso de la investigación, el carácter privado de la conversación. Y el procedimiento debe adaptarse a estas exigencias.

2. El art. 100.d.3 del Código del Procedimiento Penal establece los casos en que está prohibido investigar y gravar conversaciones. El TCF lo declaró inconstitucional porque no tiene en cuenta que no debe iniciarse tal investigación si se encuentra en el apartamento sólo el sospechoso con los miembros próximos de la familia o con sus más íntimos amigos a condición de que no 
permitía la grabación de conversaciones privadas sin los requisitos derivados del principio de legalidad. En febrero de 2006 dictó otra Sentencia declarando la inconstitucionalidad parcial de otra ley antiterrorista, el art. 14.3 de la Ley de Seguridad Aérea de 11 de enero de 2005, que había autorizado al Ministro de defensa a adoptar como última ratio la medida de derribar un avión en el que hubiera rehenes inocentes, en caso de que el avión fuera a ser utilizado para destruir vidas humanas situadas en un objetivo en tierra ${ }^{45}$.

existan indicios de que hayan participado o participen en el delito. También faltan mecanismos, en este artículo, que prevean la interrupción de una investigación en curso cuando se intervenga inesperadamente una conversación de carácter privado en el sentido mencionado. Además, este precepto debe asegurar que las informaciones obtenidas por tal investigación no sean utilizadas en un procedimiento judicial y tampoco originen investigaciones ulteriores. El TCFA no ha anulado el art. 100.3 mencionado sino que lo ha declarado inconstitucional, señalando que debe ser reformado en sentido conforme con la Sentencia del propio Tribunal, dando un plazo hasta $30 \mathrm{de}$ junio de 2005 (16 meses al legislador para ejecutar la reforma). Este tipo de decisiones (Appellentscheidüngen) son cada vez más frecuentes en la jurisprudencia alemana, pues a la vez que declaran la inconstitucionalidad, evitan una laguna inadecuada, invitando al legislador a ponerse en acción.

3. La Sentencia toma en consideración la dimensión procesal: Subraya que es necesario asegurar el derecho fundamental de la inviolabilidad del domicilio por medio de reglas procesales. El TCFA acentúa frecuentemente la dimensión procesal en el marco de la protección de la persona por los derechos fundamentales. Estas normas resultan importantes para asegurar que no tenga lugar una previa vulneración del derecho fundamental. Independientemente de esta función preventiva del derecho procesal es posible que la violación de un derecho fundamental tenga lugar por la falta de observancia de un precepto procesal. En el caso concreto el aspecto procesal se manifiesta en particular en la intervención del Juez, según el art. 100.d, apartado 2 y 4, primer y segundo inciso. El TCFA concreta las exigencias a observar por el Juez señalando que la investigación sea ejecutada respetando el contenido y la motivación de la decisión. El Juez debe indicar el tipo de la medida de investigación, la duración y las dimensiones. Si la investigación se prolonga más de lo previsto inicialmente, lo cual es posible en principio, el Juez competente (y el Ministerio Fiscal) están obligados a examinar con precisión la legitimidad de tal prolongación y a motivar particularmente la misma. Es también responsabilidad de los jueces asegurar la prohibición de utilizar como pruebas los resultados de la investigación en los casos en que esta última no estaba permitida por el carácter privado de las conversaciones investigadas.

[Se debe señalar que la temática de la protección del correo y de las conversaciones telefónicas (art. 13 LF Bonn) fue objeto de otra decisión del TCFA del mismo día. Se trataba de la Ley sobre el Comercio Exterior que permitía tal tipo de investigación para impedir delitos contra la propia Ley y de la Ley sobre el control del comercio con armas de guerra. El TCFA anuló la disposición que al respecto contenía esta Ley por su indeterminación. El Estado de Derecho exige una formulación mucho más precisa para tales autorizaciones. Un contenido tan indeterminado viola ese derecho fundamental].

${ }^{45}$ V. el excelente comentario y resumen de Rodríguez de Santiago, José María, en «Una cuestión de principios. La Sentencia del Tribunal Constitucional Federal alemán, de 15 de febrero de 2006, sobre la Ley de Seguridad Aérea, que autorizaba a derribar el avión secuestrado para cometer un atentado terrorista", $R E D C$, núm. 77, mayo-agosto 2006, págs. 257-272. La cita oficial de la 


\subsubsection{Menor alcance garantista, pero igualmente revisora de legislación} antiterrorista esl Sentencia n. 2005-532 DC, de 19 de enero de 2006, del Con-

Sentencia es BVerfG, 1 BvR 357/05 vom 15.02.2006. El texto de la Sentencia puede encontrarse en http://www.bverfg.de/entscheidungen/rs20060215_1bvr035705.html

Con los atentados de 11 de septiembre de 2001 como telón de fondo, la Sentencia tiene como ocasión próxima la reacción del Estado ante el incidente que tuvo lugar en Frankfort el 5 de enero de 2003, cuando un perturbado mental se hizo con un pequeño avión deportivo, sobrevoló el barrio financiero de la ciudad y amenazó con estrellar el aparato contra el edificio del Banco Central Europeo si no se le permitía hacer una llamada telefónica a Estados Unidos. Se declaró la alarma en la ciudad, se evacuaron los edificios, un helicóptero de la policía y dos cazas de las fuerzas aéreas vigilaron los movimientos del avión. Media hora después de que diera comienzo el incidente estaba claro que se trataba de un desvarío, que acabó cuando, una vez que se accedió a la exigencia del perturbado, éste aterrizó en el aeropuerto y se dejó detener sin resistencia.

El Estado alemán reaccionó con una amplia gama de medidas orientadas a mejorar la seguridad aérea que se incluyeron en un proyecto de ley federal que se convirtió en la Ley de Seguridad Aérea de 11 de enero de 2005. Esta estableció una medida hasta entonces desconocida: se autorizaba a intervenir a las fuerzas armadas, en colaboración con la policía de los Länder, si, como consecuencia de un incidente aéreo grave producido en un avión, fuera previsible que se desencadenara una catástrofe. Las fuerzas armadas podían intentar desviar el rumbo del avión que fuera a provocar la catástrofe o forzar a que aterrizara, amenazar con el empleo de la fuerza militar y efectuar disparos de advertencia. Como último recurso se permitía también derribar el avión cuando pudiera tenerse la seguridad de que el mismo se dirigía a destruir vidas humanas situadas en un objetivo en tierra y el disparo contra el aparato fuera el único medio de responder a la amenaza. La regulación se contiene en los arts. 13 a 15 de la mencionada Ley, concretamente, la autorización para derribar el avión se preveía en el art. 14.3. La decisión de disparar con la fuerza militar se atribuía, con carácter general, al Ministro federal de Defensa.

Contra el art. 14.3 de la Ley de Seguridad Aérea interpusieron un recurso de amparo seis ciudadanos alegando, para fundamentar su legitimación, utilizar frecuentemente, por motivos privados y profesionales, el medio aéreo de transporte. En su recurso se esgrimió argumentos relativos a la vulneración de derecho fundamentales, de un lado, y a la vulneración del orden constitucional de distribución de competencias, de otro. El Tribunal Constitucional Federal dictó Sentencia estimatoria el 15 de febrero de 2006.

El Tribunal declara inconstitucional y nulo, también por ser incompatible por el derecho a la vida (art. 2.2 LF Bonn) en relación con la garantía de la dignidad de la persona (art. 1.1 LF Bonn) el art. 14.3 de la Ley de Seguridad Aérea que, como hemos señalado, autorizaba a las Fuerzas Armadas a derribar un avión secuestrado que fuera a ser utilizado como arma contra la vida de las personas, si bien matizando que ello es así en la medida en que dicha autorización afecte a sujetos distintos de los secuestradores. En efecto, la Sentencia parte de una distinción fundamental entre, por una parte, los autores responsables del acto delictivo y, por otra, los miembros de la tripulación y los pasajeros de avión que son víctimas del secuestro. Con referencia a estos segundos el Tribunal firma la inconstitucionalidad de la previsión fundamentándola en que la dignidad del ser humano prohíbe que el Estado lo convierta en objeto de la actuación estatal y sin remedio para la salvación de otros. La decisión en este ámbito, se cierra radicalmente a cualquier forma de argumentación ponderativa, como la que podría basarse en la consideración de que, si no se dis- 
sejo Constitucional francés ${ }^{46}$ (en lo sucesivo, CCF), que ha declarado la inconstitucionalidad del art. 6.1, y del art. 19 de la Ley antiterrorismo de 2004,

para contra el avión, los que van en él morirán de todos modos unos segundos más tarde y además morirán las personas en tierra contra las que se estrelle el aparato secuestrado; mientras que, si se dispara, la muerte de unas decenas o cientos de personas podría salvar la vida de miles. El Tribunal rechaza a continuación los argumentos de los comparecientes en el proceso que iban dirigidos a una ponderación racional que relativizaba el valor del derecho a la vida de tripulación y pasajeros: vida de los que van en el avión frente a vida de todos. En cambio, la Sentencia acepta una argumentación e tipo ponderativo para concluir que el precepto no sería inconstitucional si únicamente permitiera derribar un avión en el que sólo se encuentren los que pretenden utilizar el aparato como arma contra las personas en tierra. La ratio decidendi de la Sentencia es que la dignidad de la persona excluye que se trate al ser humano como simple objeto o medio de la acción estatal.

46 Para el comentario de la misma seguimos el de Calamo Specchia, Marina, «Al vaglio del Conseil constitutionnel la loi anti-terroriste: il fine giustifica i mezzi?», en Diritto pubblico comparato ed europeo, 2006-II, G. Giappichelli Editore, Torino, pp. 722 y ss.; puede verse igualmente Avril, P., Gicquel, J., "Le trionphe de l'entonnoir'», en Les petites affiches, 15 de febrero de 2006, n. ${ }^{\circ} 33$, pp. 6-9; Brondel, S., «Le Conseil constitutionnel durcit sa jurisprudence sur le droit d'amendement», en Act. Jur. Dr. Adm., 2006, p. 172 ; Daleau, J., "Validation de la loi contre le terrorisme et précisions sur le droit d'amendement», en Dalloz, 2006, p. 247; y Schoetti, J. E., «La législation anti-terroriste à l'épreuve du contrôle de constitutionnalité», en Gazette du Palais, 5/7 de febrero de 2006, n. ${ }^{\text {os }} 36-38$, pp. 20-39.

El art. 6 de la Ley impugnada introducía en el código postal y de las telecomunicaciones un nuevo art. 34.1 que permitía a agentes individualmente autorizados de los servicios de policía especializada en la prevención del terrorismo acceder a los datos llamados «de tráfico», que son el subproducto de las conexiones informáticas a la red, relativos a las comunicaciones electrónicas, salvo el contenido de las mismas. Se establece, por tanto, un procedimiento administrativo para recavar datos técnicos de conexión «a fin de prevenir y reprimir los actos de terrorismo». La originalidad, y al mismo tiempo la duda de constitucionalidad, de la disposición radica en la transferencia de poderes represivos de naturaleza penal desde la esfera de la policía judicial a la esfera de la policía administrativa. Los recurrentes consideraban que el art. 6 de la Ley antiterrorismo atribuía poderes represivos a la policía administrativa, sustrayendo al control judicial actos susceptibles de violar la libertad individual y el derecho a la intimidad, con lo que el legislador habría privado de garantías legales algunos bienes constitucionalmente protegidos.

El art. 6 de la ley antiterrorista presenta algún vicio de constitucionalidad en la medida en que atribuye a la policía administrativa no sólo funciones de prevención, sino también de represión de actos terroristas. Tal previsión legislativa viola el principio de separación de poderes, sobre el cual el Consejo Constitucional ejerce un control constante y cuidadoso, al sustraer las medidas de represión de actos terroristas al poder de control de la autoridad judicial, que desarrolla una función de garantía. El CCF, por tanto, declara contrario a la Constitución el art. 6 por violación del principio de separación de poderes en la parte en que prevé un régimen de control unitario para la prevención y para la represión de actos terroristas y rechaza, del texto del art. 6 las palabras «y de reprimir", por considerarlas inconstitucionales. $\mathrm{Al}$ ser las palabras inconstitucionales separables del contexto de referencia, el resto del art. 6 se considera conforme a la Constitución. 
que establecían, respectivamente, poderes de represión de los delitos a la policía administrativa que vulneraban el principio de separación de los poderes y que contenía disposiciones extrañas a la represión de actos de terrorismo (los llamados «cavaliers législatifs»).

3.3.3. En cuanto a los jueces ingleses, con una sentencia de 16 de diciembre 2004, la Cámara de los Lores consideró ilegal el encarcelamiento indefinido sin previsión de juicio de extranjeros sospechosos de tener vínculos con el terrorismo, prevista en el artículo 23 de la ley de 2001, considerando esta medida injustamente discriminatoria sobre la base de la nacionalidad de los inmigrantes y desproporcionada respecto de la propia derogación permitida por el artículo 15 de Convenio Europeo.

3.3.4. Entre nosotros, el Tribunal Constitucional ha puesto algún obstáculo a la legislación antiterrorista en el pasado, pero en los últimos años se ha alineado con el legislador. En concreto, nuestro Tribunal Constitucional ha vali-

El art. 17 de la Ley antiterrorista, introduce cuatro apartados en el art. 706-88 del Código de procedimiento penal con los que modifica el régimen de la detención, prolongando los plazos de la misma con referencia a los delitos relacionados con el terrorismo: la duración de la medida se amplía a 144 horas, o sea, 6 días, que equivalen a 48 horas más del mínimo de custodia preventiva que estaba en vigor con anterioridad en Francia para las infracciones más graves. Este endurecimiento de la detención se considera que respeta la libertad individual y que es compatible con las exigencias constitucionales según la jurisprudencia en materia de intervención necesaria de la autoridad judicial con base en el art. 66 de la Constitución francesa (decisión del CC 93-326 DC de 11 de agosto de 1993), así como con la jurisprudencia relativa a la proporcionalidad de la medida (CC, decs. nn 80-127 DC de 20 de enero de 1981; 86-213 DC de 3 de septiembre de 1986, y 2004-492 DC de 2 de marzo de 2004).

Estas medidas nuevas establecen una posibilidad de prórroga suplementaria de los plazos de detención siempre que concurran determinados requisitos: el carácter excepcional de la medida que se aplica solamente en dos hipótesis taxativamente previstas, cuando exista un serio riesgo de una inminente acción terrorista en Francia y cuando lo requieran de manera inaplazable exigencias de cooperación internacional.

La medida de prolongación de los plazos de detención puede ser concedida solo por medio de acuerdo motivado de la autoridad judicial, y en caso de que concurran los presupuestos es necesario además un dictamen médico acerca de la compatibilidad de la medida con el estado de salud del interesado antes del inicio de la medida cautelar.

Por lo que se refiere, en fin, a la consulta de un abogado, que constituye uno de los componentes del derecho de defensa, por parte de la persona sometida a medida cautelar, el Consejo Constitucional ha considerado que el legislador es competente para establecer un plazo distinto en función de las infracciones cometidas: se trata, en tal hipótesis, de la redeterminación de las modalidades de ejercicio de tal derecho en relación con la naturaleza de las infracciones cometidas, cuya gravedad vuelve a poner en discusión la amplitud del principio del derecho de defensa. 
dado la ley de partidos y las resoluciones administrativas y judiciales que la han aplicado. Algo parecido cabe señalar con referencia al Tribunal Supremo. Es preciso señalar, en efecto, que los dos únicos intentos de disolución del partido Batasuna (anteriormente Herri Batasuna) planteados respectivamente en 1984 y 1986 fueron rechazados por el Tribunal Supremo por cuanto no se basaban en la concurrencia concreta de ilícitos penales o actividades anticonstitucionales, sino en una mera interpretación del estatuto de la asociación. Pero con posterioridad ha secundado la política antiterrorista de la Ley de partidos.

\section{A. Papel desarrollado por el Tribunal Supremo}

A.1. Es muy difícil hacer una valoración de conjunto de la aplicación por parte del Poder judicial, y en particular del Tribunal Supremo, de la legislación antiterrorista, y acaso no tenga sentido plantearse la cuestión. Incluso calificar como más o menos garantistas las resoluciones judiciales depende de la perspectiva ideológica del observador, ya que supuestamente las resoluciones judiciales, todas, se limitan a aplicar la ley. Pero sí cabe apuntar algunas resoluciones que han sido valoradas como garantistas por la doctrina, en ocasiones incluso por la opinión pública. A veces, pues, el Tribunal Supremo ha jugado un papel moderador de las iniciativas gubernamentales, plasmadas en reformas legislativas.

A.1.1. En este sentido, ha matizado el delito de colaboración en el delito de terrorismo indicando que lo que se sanciona en el mismo no es la adhesión ideológica, sino poner medios a disposición de una organización armada para que prosiga la consecución de sus fines, precisamente a través de la violencia ${ }^{47}$.

A.1.2. Particular interés tiene el rechazo del planteamiento de la lucha antiterrorista encarnado en la base de Guantánamo. El Tribunal Supremo en su Sentencia de 20 de julio de 2006, absolvió a don Hamed Abderrahaman Ahmed, conocido por «Hmido» o periodísticamente por «el talibán español», casando la Sentencia dictada por la Sección $4 .^{a}$ de la Sala de lo penal de la Audiencia Nacional de 4 de octubre de 2005 por la que se le había condenado

${ }^{47}$ Según la jurisprudencia del Tribunal Supremo, tenemos que estar en presencia de una actividad que favorezca la comisión de delitos (STS 3 de junio de 1983) o ayude a los miembros de la organización terrorista para los fines ilícitos perseguidos (STS 17 de marzo de 1983) o favorezca las actividades y fines de la banda armada (STS 26 de mayo de 1992), en todo caso, algo más que la mera afinidad ideológica (STS 9 de marzo de 1990), pues lo que no se incrimina es un mero proyecto político (STS 28 de junio de 1995). 


\section{como autor responsable penalmente de un delito de integración o pertenencia a organización terrorista a la pena de seis años de prisión ${ }^{48}$. El Tribunal Supremo}

${ }^{48}$ Las concretas denuncias efectuadas en el recurso, en palabras de la Sentencia del Tribunal Supremo, fueron las siguientes: a) Utilización por la Sentencia de palabras tales como «Yihad», «tnuyahidines», "talibán» con un contenido inequívocamente delictivo, existiendo además una clara falta de motivación que pudiera justificar el fallo condenatorio. b) Valoración en la Sentencia de la declaración de los agentes policiales españoles, funcionarios de la Unidad Central de Información Exterior - UCIE - que se desplazaron a la base militar de Guantánamo. c) Nulidad de la declaración en sede judicial del recurrente cuando ya se encontraba en España, estimándose también nula por su estado de salud. d) Insuficiente prueba de cargo para dictar la Sentencia condenatoria al existir solo indicios insuficientes y no motivados. e) La quinta denuncia se realizaba desde la perspectiva de la nulidad de las pruebas obtenidas con violación de derechos fundamentales.

La Sentencia del Tribunal Supremo es impecable desde un punto de vista penal y procesalpenal. En efecto, la condena de la Audiencia Nacional se había basado en que el acusado se interesaba por la Yihad y por la interpretación de la religión islámica realizada por los talibanes, porque se había trasladado a Afganistán y allí había estado en una madraza (escuela islámica del Corán), y en que allí fue detenido por el ejército americano y luego trasladado a la prisión de Guantánamo.

Si analizamos la Sentencia de la Audiencia Nacional de 4 de octubre de 2005 podemos comprobar cómo la prueba de cargo se basa en la declaración del acusado en sede judicial, ante el Juez de instrucción, estimando que respecto de esta declaración no existe conexión de antijuridicidad con lo declarado por el acusado cuando se encontraba recluido en Guantánamo; en la «entrevista policial realizada en Guantánamo»; en la intervención telefónica acordada en las D.P. 24/2001, ajenas a este proceso, y en la declaración realizada en el juicio oral por los agentes policiales que le entrevistaron en Guantánamo, como testigos de referencia en virtud de lo establecido en el artículo 710 de la LECr.

Salvo la declaración en sede judicial, nos encontramos con que todas y cada una de las pruebas de cargo utilizadas sólo podrían ser válidas para obtener la condena del acusado en el marco de la aplicación del Derecho penal del enemigo. La intervención telefónica reseñada incumplía los requisitos establecidos por la jurisprudencia del Tribunal Supremo, y así se denuncia en el proceso, y aún así es utilizada por la Audiencia Nacional. Con posterioridad el propio Tribunal Supremo en su Sentencia 556/2006, de 31 de mayo, en la causa origen de la misma la declara nula. En cuanto a la denominada por la Audiencia Nacional «entrevista» policial desarrollada en la base militar norteamericana de Guantánamo, se efectúa sin asistencia de letrado, sin información previa de los derechos constitucionales, fuera de los mecanismos de asistencia judicial internacional, sin autorización del Juzgado de Instrucción que conocía la causa y estando Hamed privado de libertad y en una situación de presión al menos psicológica que excluiría su voluntariedad. Se trae al proceso como prueba de cargo a través de los policías como testigos de referencia. Pero afirma el Tribunal Supremo en la Sentencia que «constituiría un verdadero fraude procesal estimar nula la declaración del recurrente y recuperarla o rescatarla por vía indirecta a través del testimonio de los interrogadores bajo el subterfugio del art. 710 LECr: testigos de referencia».

Por último, se utilizó como prueba de cargo la declaración de Hamed en el acto del juicio. Examinada esta declaración por el Tribunal Supremo, éste llega a conclusiones totalmente contrarias a las que había llegado la Audiencia Nacional. Las mismas palabras llevan a conclusiones to- 
en esta Sentencia analiza brevemente la problemática de los detenidos en la base americana de Guantánamo como ejemplo de lo que la doctrina ha definido como "Derecho Penal del Enemigo» y realiza una afirmación clara sobre el mismo: «Se trata de una construcción jurídica que parte de una contradicción en sus argumentos que contamina hasta la propia denominación de la doctrina. No se pueden defender desde el Estado los valores de la libertad, convivencia, pluralidad y Derechos Humanos, con iniciativas caracterizadas por la vulneración de los valores que se dicen defender (...) el derecho penal del enemigo, vendría a ser, más propiamente la negación del derecho penal en la medida que trata de desposeer a sus posibles destinatarios de algo que les es propio e inderogable: su condición de ciudadanos de la polis».

A.2. Pero en definitiva el Poder judicial está sometido al principio de legalidad y por tanto pueden encontrarse también sentencias que se perciben como una prolongación de la actitud gubernamental, lo que no es de extrañar, toda vez que en un sistema parlamentario el Gobierno lidera la actividad legislativa, con lo que acaba por condicionar la actividad judicial. No debe perderse de vista, además, que como es sabido, por imperativo constitucional (art. $124 \mathrm{CE}$ ), el Ministerio Fiscal tiene una estructura jerárquica y está encabezado por el Fiscal General del Estado, nombrado por el Rey a propuesta (vinculante, por ser el sistema parlamentario) del Gobierno.

A.2.1. Una Sentencia que podría ser alineada como prolongación de la legislación antiterrorista, por más que no esté exenta de matices decididamente garantistas, es la del Tribunal Supremo de 29 de noviembre de $1997^{49}$. Los hechos estimados probados por el Tribunal Supremo y que fueron declarados constitutivos del delito de colaboración con el delito de terrorismo vinieron a consistir en

talmente diferentes. Sirva como ejemplo, cómo se interpretó el ejercicio del derecho a la última palabra del acusado. Éste dijo: «soy un mártir, pasé muchos sufrimientos en Guantánamo, que son difíciles de explicar, que me han destrozado la vida...». Para la Sentencia que le condenó esta declaración significaba su comunión con el fundamentalismo islámico en clave de autoinmolación terrorista. En cambio, el Tribunal Supremo consideró que Hamed afirmó era un mártir porque sufrió, sin justificación, sin proceso y sin derechos una privación de libertad en unas condiciones durísimas.

49 Sigo la magnífica síntesis que ofrece Gutiérrez Gil, Andrés Javier, «La participación por colaboración en el delito de terrorismo", en La criminalidad organizada. Aspectos sustantivos, procesales y orgánicos, Cuadernos de Derecho Judicial II-2001, Escuela Judicial-Consejo General del Poder Judicial, Madrid, 2001, pp. 13 y ss., con un brillante análisis de este delito y de las STS 29 de noviembre de 1997 y STC 136/1999, de 20 de julio. 
aceptar para la propaganda electoral materiales procedentes de ETA y en cederle a ésta los espacios gratuitos en los medios de comunicación. El Tribunal Supremo absuelve a los procesados (los miembros de la Mesa de HB) por delito de pertenencia a banda armada y por delito de apología, y condena a cada uno de ellos, como autores de un delito de colaboración con banda armada, a una pena de siete años de prisión y accesorias ${ }^{50}$. Se trata de una Sentencia sobre cuyos avatares posteriores volveremos, por considerarlos muy importantes para la evolución del Derecho antiterrorista español.

A.2.2. Un conjunto de sentencias que se pueden percibir como prolongación de la política antiterrorista gubernamental son las dictadas en aplicación de la Ley de Partidos de 2002. En efecto, una vez publicada la ley, (Ley Orgánica 6/2002, de 27 de junio, de Partidos Políticos), siguiendo las previsiones de la misma, el Gobierno y el Ministerio Fiscal solicitaron del Tribunal Supremo la ilegalización de unos partidos determinados, por considerarlos brazos políticos de la organización terrorista ETA: Herri Batasuna (HB), Euskal Herritarrok (EH) y Batasuna. El Tribunal Supremo dictó sentencia de 27 de marzo de 2003 que estimó los recursos presentados por el Gobierno y el Ministerio Fiscal y disolvió los partidos mencionados. Esta Sentencia del Tribunal Supremo sería recurrida en amparo ante el Tribunal Constitucional, como veremos, pero antes de que se resolviera el correspondiente recurso se convocaron elecciones municipales y a ellas se presentaron un amplio número de agrupaciones de electores que encarnaban a los partidos disueltos. Ahora bien, la Ley de Partidos había

${ }^{50}$ La acusación por delito de apología del terrorismo fue formulada por las acusaciones particulares personadas en el procedimiento. Dicha acusación se basaba en los contenidos de sendos comunicados emitidos por la Coalición inmediatamente después de los asesinatos de Fernando Múgica Herzog y de Francisco Tomás y valiente, (Expresidente del Tribunal Constitucional), ambos en el mes de febrero de 1996.

En la Sentencia de 29 de noviembre de 1997 se absuelve a los procesados por delito de pertenencia a banda armada y por delito de apología, y se condena a cada uno de ellos, como autores de un delito de colaboración con banda armada, a una pena de siete años de prisión y accesorias.

La entrada en vigor del nuevo Código penal en mayo de 1996 indefectiblemente conduciría a la aplicación retroactiva del artículo 18 y en consecuencia a la absolución por el delito de apología.

Ahora bien, el Tribunal Supremo condena por el delito de colaboración con la organización terrorista. La inclusión de la conducta de los viciados en el tipo penal se apoyó en la expresa referencia a las «ayudas de otro género» que el artículo 174 bis a) recogía como cláusula abierta. Una cláusula cuya inconstitucionalidad fue planteada por la defensa de los procesados, a lo que el Tribunal contestó negativamente apoyándose en la jurisprudencia constitucional, que admite la compatibilidad de las cláusulas abiertas o conceptos indeterminados con el artículo 25.1 CE. 
previsto esta posibilidad en su artículo 12. Y de este modo, en aplicación de este precepto, el Gobierno, a la sazón del Partido Popular, y el Ministerio Fiscal presentaron recurso contencioso electoral contra la proclamación de las candidaturas de las agrupaciones de electores que se consideraba representaban la continuidad de los partidos disueltos. El Tribunal Supremo, en dos sentencias de 3 de mayo de 2003, estimó los referidos recursos y anuló las candidaturas. En la misma línea, otra sentencia del Tribunal Supremo, de menor importancia, de 5 octubre de 2003, desestimó el recurso presentado por una agrupación electoral contra la denegación de la proclamación de su candidatura por parte de la Administración electoral. Algo similar ocurrió en las siguientes elecciones al Parlamento Europeo convocadas el 19 de abril de 2004. A instancia del Gobierno y del Ministerio Fiscal, el Tribunal Supremo dictó Sentencias de 21 de mayo de 2004 que anularon la proclamación de la candidatura que determinada agrupación electoral por considerarla continuadora de los partidos disueltos por la Sentencia del Tribunal Supremo de 27 de marzo de 2003.

También en las elecciones locales de 2007 el Tribunal Supremo estimó las demandas interpuestas por Abogado del Estado y Ministerio Fiscal. Concretamente, por Sentencia de 5 de mayo de 2007, estimó los recursos contencioso electorales interpuestos por el Abogado del Estado y el Ministerio Fiscal contra la proclamación de las candidaturas de 235 agrupaciones electorales de distintas corporaciones locales del País Vasco. Además, por Auto de 5 de mayo de 2007, estimó las demandas interpuestas por el Abogado del Estado y del Ministerio Fiscal recurriendo determinadas candidaturas presentes en 21 localidades por Eusko Abertzale Ekintza-Acción Nacionalista Vasca (EAE-ANV).

Pero estas últimas sentencias a las que acabamos de hacer referencia tienen un alcance político distinto de las de 2003 a las que hemos aludido con anterioridad. En efecto, en 2003, gobernaba el Partido Popular y había un pacto antiterrorista entre este partido y el Partido Socialista que hizo que la Ley de Partidos, la impugnación de las candidaturas y las Sentencias subsiguientes impidieran el acceso de ETA y su brazo político a las instituciones democráticas. Este era el sentir en aquel momento tanto el Partido Popular como del Partido Socialista obrero español.

En el año 2007 la situación ha sido distinta. El pacto antiterrorista entre Partido Popular y Partido Socialista ya no está vigente y el Gobierno, ahora del Partido Socialista, ha mantenido durante buena parte de la legislatura, negociaciones con ETA para lograr la llamada pacificación de Euskadi. Ciertamente, el Gobierno dice aplicar la Ley de Partidos, y tanto el Abogado del Estado como el Ministerio Fiscal han interpuesto acción ante el Tribunal Supremo contra determinadas candidaturas, acciones que prosperaron ante el Tribunal Supremo y 
luego, como veremos, ante el Tribunal Constitucional. Pero para el Partido Popular, ahora en la oposición, el Gobierno debería, en ejecución de la Ley de Partidos, instar la ilegalización de ANV y disolver los 49 ayuntamientos en los que gobierna. Para el Partido Popular, ETA aprobó una falsa tregua para lograr que ANV se pudiera presentar a las elecciones, pero lo cierto es que ANV no ha condenado ningún atentado cometido por ETA, ha compartido sedes con Batasuna y se han probado en definitiva relaciones estrechas entre Batasuna y ANV, por lo que, en aplicación de la Ley de Partidos, debería instarse la disolución de este último partido ${ }^{51}$.

Naturalmente, el Tribunal Supremo sólo puede actuar a instancia del Gobierno o del Ministerio Fiscal, y este último, como ya hemos señalado con anterioridad, tiene cierta dependencia del Gobierno en España.

A.2.3. Una idea generada durante los Gobiernos del Partido Popular (19962004), para la política antiterrorista es la de alargar las penas no sólo formalmente, sino de manera práctica y efectiva. Esta idea, como hemos visto, ha alcanzado plasmación legislativa en la Ley Orgánica 7/2003, de 30 de junio, de medidas de reforma para el cumplimiento íntegro de las penas. Pero además e independientemente de esta plasmación legal, el Tribunal Supremo ha acogido esta idea alumbrando en la Sentencia 197/2006, de 28 de febrero, (caso Enrique Parot), un nuevo método para el cómputo del licenciamiento definitivo de los penados. Según esta doctrina, y frente a la unánime práctica anterior de los órganos judiciales, las redenciones ordinarias o extraordinarias que los penados hayan obtenido durante el cumplimiento de las diversas condenas que les hayan sido impuestas y cumplan sucesivamente, se deducirá de la suma aritmética de las penas que hayan sido impuestas, y no del límite máximo de su cumplimiento que haya sido fijado en aplicación de las previsiones del arte $76 \mathrm{CP}$ (normalmente 20, 30 años o el triple o de la mayor de las penas impuestas).

\section{B. Papel desarrollado por el Tribunal Constitucional}

B.1. La legislación antiterrorista, y en particular el desarrollo del art. 55.2 $\mathrm{CE}$, han evolucionado a lo largo de los ya casi treinta años de vigencia de la

51 Véase, por ejemplo, Yanel, Agustín, «El Congreso rechaza la propuesta del PP para ilegalizar ANV y sus ayuntamientos», en El Mundo, miércoles 17 de octubre de 2007, p. 12; Díez, Anabel, «El Congreso rechaza la exigencia del PP de ilegalizar ya a ANV», en El País, miércoles 17 de octubre de 2007, p. 20; López Alba, Gonzalo, «El Congreso pide al PP que vuelva a la 'unidad de los demócratas'", Público, miércoles, 17 de octubre de 2007, p. 18. 
Constitución. Durante los primeros años, se aprobaron leyes que de manera separada y orgánica desarrollaron el art. 55.2 CE. Como quiera que las mismas fueron bastante criticadas por la doctrina, desde 1988 (leyes orgánicas 3 y 4/1988, de 25 de mayo, de reforma del Código Penal y de la Ley de Enjuiciamiento Criminal, respectivamente), las previsiones que desarrollan el art. 55.2 $\mathrm{CE}$ se encuentran, de manera vergonzante, en leyes ordinarias.

En la evolución de la legislación antiterrorista ha influido la aplicación de los tribunales y la crítica de la doctrina científica ${ }^{52}$. Pero en este diálogo entre legislativo (liderado por el Gobierno) y jurisdicción (englobando aquí al Tribunal Constitucional, si bien el mismo, en España, está separado del Poder judicial) ha jugado un papel destacado el Tribunal Constitucional, como no podía ser de otra manera, toda vez que él a diferencia del Poder judicial en general y del Tribunal Supremo en particular, no está, sujeto a toda la legalidad, sino sólo a la Constitución y a su propia Ley Orgánica.

B.2. De modo que los sucesivos desarrollos del art. 55.2 CE, las sucesivas legislaciones antiterroristas, han sido con frecuencia objeto de control de constitucionalidad por el Tribunal Constitucional, que algunas veces las ha recortado y otras ha salvado su constitucionalidad aprobando sentencias interpretativas.

A la legislación antiterrorista de 1984 seguiría la STC 199/1987, de 16 de diciembre, que resolvió dos recursos de inconstitucionalidad planteados por los Parlamento Catalán y Vasco contra la Ley Orgánica 9/1984, de 26 de diciembre, (contra la actuación de bandas armadas y elementos terroristas y de desarrollo del art. 55.2 CE). El Tribunal excluyó la aplicación de la propia Ley a la apología de los delitos contenidos en la misma (declarando la inconstitucionalidad del art. 1.1, inciso segundo); declaró inconstitucional la posibilidad de extender la prisión preventiva 7 días más de las 72 horas siguientes a la detención (declarando inconstitucional el art. 13); salvó la posibilidad de incomunicación del detenido, pero exigiendo que la ley se interpretara en el sentido de que el acuerdo gubernativo de incomunicación debe ser objeto de simultánea solicitud

52 Así por ejemplo, el delito de apología del terrorismo ha recibido no menos de seis configuraciones distintas desde 1978: Decreto/Ley 3/1979, de 26 de enero, sobre Protección de la Seguridad Ciudadana; Ley Orgánica 4/1980, de 21 de mayo, que dio nueva redacción a los arts. 268 y 566.4 del Código Penal; Ley Orgánica 2/1981, de 4 de mayo que estableció el art. 216 bis; Ley Orgánica 9/1984, de 26 de diciembre, de Medidas contra la actuación de bandas armadas y actividades terroristas o rebeldes, art. 10; Ley Orgánica 10/1995, de 23 de noviembre, del Código Penal, art. 18.1, párrafo segundo; Ley Orgánica 7/2000, de 22 de diciembre, de modificación de la Ley Orgánica 10/1995, del Código Penal y de la Ley Orgánica 5/2000, de 12 de enero, reguladora de la responsabilidad penal de los menores, que da nueva redacción al art. 578 del Código Penal. 
de confirmación al órgano judicial competente; declaró inconstitucional el cierre de un medio de comunicación cuando se admita una querella contra el mismo por los delitos contemplados en la ley (declarando inconstitucional el art. 21) e indicó que el concepto de «bandas armadas» no podía interpretarse ampliamente, sino restrictivamente y en relación con «elementos terroristas».

A la legislación antiterrorista de 1988 siguió la STC 71/1994, de 3 de marzo. La referida Sentencia resolvió un recurso de inconstitucionalidad planteado contra la Ley Orgánica 4/1988, de 25 de mayo, que introdujo dos nuevos artículos en la Ley de Enjuiciamiento Criminal: el 384 bis y el 504 bis. El Tribunal Constitucional declaró la inconstitucionalidad del mencionado art. 504 bis LE Crim nuevo, que establecía que cuando el Ministerio Fiscal recurriera en reforma o en apelación una resolución judicial que hubiera acordado la libertad de un preso o detenido por delito de terrorismo, ello conllevaría la suspensión de la excarcelación por un periodo máximo de un mes.

B.3. Pero el Tribunal Constitucional no sólo controla la constitucionalidad de las leyes directamente, sino también la adecuación de la aplicación de éstas por parte del Poder judicial, control que le corresponde desde el punto de vista del sistema de las garantías constitucionales ${ }^{53}$.

En este aspecto es de gran interés la STC 136/1999, de 20 de junio, que anuló la STS de 29 de noviembre de 1997, que, como hemos visto anteriormente, condenó a los componentes de la Mesa Nacional de HB por entender que los mismos habían realizado «un acto de colaboración con ETA, concretado en la decisión adoptada por los componentes de la Mesa Nacional de HB en su reunión de 5 de febrero de1996, de ceder a una organización terrorista los espacios electorales gratuitos que como formación política le correspondían, asumiendo de esta forma su contenido». El Tribunal Constitucional consideró contrario al principio de proporcionalidad el art. 174 bis a) del Código Penal de 1973 (que se corresponde con el art. 576 del vigente Código Penal), por cuanto consideraba demasiado elevada la pena mínima que el precepto obligaba a imponer y que consistía en prisión de 5 años.

Sin embargo, el legislador no acogió el mensaje. Ciertamente hubo un Anteproyecto de reforma del Código Penal que reducía la pena mínima a tres años de prisión, pero no llegó a ser aprobado. Con posterioridad se ha realizado

53 En la STC 159/1986, de 16 de diciembre, el Tribunal anuló la condena al Director del Diario Egín por la inserción de comunicados de ETA y destacó la importancia del requisito de la asunción de los hechos delictivos como algo positivo y encomiable para incurrir en el delito de apología del terrorismo. 
alguna reforma del Código Penal, como la contenida en la Ley Orgánica 7/2000, de 22 de diciembre, pero se ha dejado intacto el art. 576 CP [equivalente al art. 174 bis a) del Código Penal de 1973]. Ahora bien, esta Sentencia tuvo una gran trascendencia porque descorazonó al Gobierno respecto del empleo de la vía penal para luchar contra el brazo político de ETA y de esta manera acabó generando la peculiar Ley de Partidos de 2002, como vía adicional a la penal desde el punto de vista jurídico, pero que de hecho ha venido a desplazar a la utilización de esta última.

B.4. El Tribunal, aunque introdujo algún matiz, ha considerado constitucional la Ley de Partidos ${ }^{54}$ y su aplicación por el Tribunal Supremo.

La Ley de Partidos Políticos de 2002 fue considerada constitucional, dictándose al respecto una Sentencia interpretativa. En efecto, la STC 48/2003, de 12 de marzo, rechazó el recurso de inconstitucionalidad interpuesto por el Gobierno Vasco (del Partido Nacionalista Vasco) contra la Ley Orgánica 6/2002, de 27 de julio de Partidos Políticos. Se trata de una Sentencia interpretativa que lima las aristas constitucionalmente discutibles y discutidas de la ley, precisando qué es apoyo tácito al terrorismo, el alcance de la negativa de un partido político a condenar atentados terroristas, el significado y efectos de la anulación de una candidatura presentada por una agrupación de lectores, o los supuestos de denegación de inscripción. Interesa destacar en ella una idea básica: se funda en que el legislador, como la propia Constitución, no había pretendido establecer un modelo de "democracia militante», toda vez que la ley preveía consecuencias jurídicas para comportamientos concretos, no para programas o ideologías ${ }^{55}$.

En la STC 85/2003, de 8 de mayo, el Tribunal Constitucional resolvió algo más de 420 recursos de amparo interpuestos contra dos Sentencias del Tri-

${ }^{54} \mathrm{La}$ jurisprudencia constitucional sobre partidos políticos es relativamente abundante. La doctrina general se encuentra en la STC 85/1986, de 25 de junio, relativa al Partido Comunista de Aragón. Especial relevancia tiene la STC 21/1983, de 22 de marzo, relativa al partido de recuperación y unificación de los comunistas, respecto de los efectos de la inscripción de los partidos políticos en el registro. La aplicación de la protección del art. $22 \mathrm{CE}$ y por tanto del recurso de amparo a los partidos políticos se encuentra en la temprana STC 3/1981, de 2 de febrero, relativa al PCE m-l, formulándose también la idea de la exclusividad del Poder Judicial para pronunciarse sobre la legalidad de un partido político. También es relevante la STC 56/1995, de 6 de marzo, relativa a la expulsión de un afiliado de su partido, a la obligación de democracia interna y a la garantía judicial de los derechos de los afiliados.

55 La doctrina ha discutido, con razón, este fundamento. Ha de tenerse presente que en la doctrina española es dominante la postura que considera que existen límites implícitos al poder de reforma de la Constitución, lo que tiene una obvia afinidad con la idea de admitir que se trata de una democracia militante, como por lo demás seguramente es el caso de todas las democracias actuales. 
bunal Supremo de 3 de mayo de 2003, que habían estimado los recursos contencioso electorales contra los actos de proclamación de candidaturas de las Juntas Electorales del País Vasco que habían considerado válidas las candidaturas de agrupaciones de electores que entrañaban la continuidad con la ya disuelta Herri Batasuna. El Tribunal Constitucional aplica la doctrina de la STC 48/2003 a este caso concreto y básicamente confirma el parecer del Tribunal Supremo, introduciendo tan solo algún matiz. En efecto, señala que los criterios para considerar una agrupación electoral continuadora de Herri Batasuna deben interpretarse con extremado rigor. De esta manera, sostiene que procede estimar los recursos interpuesto por aquellas agrupaciones electorales cuya integración en la trama defraudatoria se acredita con el dato de la inclusión entre los componentes de la candidatura de una sola persona relacionada organizativamente con los partidos disueltos. Además, otorga también el amparo a aquellas candidaturas en las que, aunque presenten un número superior de candidatos relacionados con los partidos disueltos, no concurran acumuladamente una serie de factores como son, entre otros, un porcentaje significativo de candidatos vinculados con los partidos disueltos, un puesto relevante en la candidatura, la participación y eventual elección en anteriores comicios en las listas de los partidos ilegalizados, la ocupación de cargos institucionales en representación de dichos partidos, la posición ocupada en la estructura de éstos, o la eventual implicación en la trama defraudatoria. En aplicación de estos criterios se estiman en total 30 recursos de amparo de los aproximadamente 420 que se habían interpuesto ${ }^{56}$.

La STC 5/2004, de 16 de enero, desestimó el recurso de amparo promovido por el partido Batasuna contra su ilegalización por STS de 27 de marzo de $2003^{57}$. Se mueve en la línea de la anteriormente referida 48/2003: la Constitución española no establecería una «democracia militante» porque no incluye una cláusula de intangibilidad absoluta, la negativa de un partido a condenar atentados terroristas puede constituir, en determinadas circunstancias, un apoyo tácito, etc.

56 Siguiendo la estela de la STC 85/2003, otra sentencia de menor importancia, la STC 176/2003, de 10 de octubre, estimó el recurso de amparo interpuesto por una agrupación electoral contra la Sentencia del Tribunal Supremo de 5 de octubre de 2003 que había excluido la candidatura presentada por la agrupación electoral recurrente en amparo. El Tribunal Constitucional señala que el único indicio disponible del que se había deducido la continuidad o sucesión era la presencia del candidato único de la agrupación a Presidente de concejo abierto en una lista excluida de las anteriores elecciones municipales e integrando otra de uno de los partidos disueltos en las municipales de 1999.

57 Y contra Auto del Tribunal Supremo de 4 de diciembre de 2002 que había desestimado la recusación formulada contra el propio Presidente del Tribunal. 
En la STC 6/2004, de 16 de enero, el Tribunal Constitucional desestimó el recurso de amparo de Herri Batasuna contra su ilegalización, recurso de amparo que era planteado con particular incidencia en la perspectiva del derecho de asociación política.

También el Tribunal Constitucional consideró válidas las Sentencias del Tribunal Supremo de 21 de mayo de 2004, que excluyeron a determinadas agrupaciones electorales de las elecciones al Parlamento Europeo. Por lo que se refiere al derecho de participación política, la Sentencia es básicamente aplicación de la doctrina de la STC 85/2003.

Las sentencias del Tribunal Constitucional dictadas con motivo de las elecciones locales de 2007 han confirmado el criterio del Tribunal Supremo, aplicando la doctrina de la STC 85/2003 y demás sentencias posteriores que aplicaron ésta. En la STC 110/2007, de 10 de mayo, se desestimaron 20 recursos de amparo interpuestos por un total de 235 agrupaciones electorales contra la anulación de la proclamación de las candidaturas por STS de 5 de mayo de 2007. En la STC 112/2007, de 10 de mayo se desestimó el recurso de amparo interpuesto por Acción Nacionalista Vasca contra Autos del Tribunal Supremo de 4 y 5 de mayo que habían supuesto la anulación de las candidaturas de determinadas candidaturas presentadas por este partido político.

Como hemos señalado anteriormente, con una misma Ley de Partidos y con una misma jurisprudencia del Tribunal Supremo y del Tribunal Constitucional aplicativa de la misma, la situación jurídico política es muy distinta en 2003 y en 2007. Como quiera que tanto el Tribunal Supremo como el Tribunal Constitucional actúan a instancia de la Abogacía del Estado o del Ministerio Fiscal, en 2007 no entraron a controlar muchas candidaturas que según el Partido Popular implican la continuación de los partidos ilegalizados.

\section{HACIA UN NUEVO PARADIGMA DEL DERECHO ANTITERRORISTA}

A. La última parte del trabajo consiste en resumir las reflexiones que suscita el estudio de este acervo legislativo y jurisprudencial.

Las resumo antes telegráficamente:

1. Aunque el fin del Estado sea la garantía de los derechos fundamentales, los problemas que plantean las limitaciones de los derechos fundamentales por razón de la lucha contra el terrorismo no pueden resolverse planteándolo meramente como conflicto entre libertad y seguridad. 
2. Ninguno de los tres paradigmas clásicos para afrontar la violencia ilegítima, esto es, el Derecho penal, el Derecho de la guerra y el Derecho de excepción, sirven plenamente para hacer frente al terrorismo. Es preciso configurar el llamado estado de tensión.

3. Es conveniente un anclaje constitucional bien del estado de tensión, bien de la legislación especial, en lo que puede considerarse pionera nuestra Constitución vigente.

4. Punto irrenunciable del nuevo paradigma es el principio de universalidad de los derechos humanos.

5. El acervo jurisprudencial del TEDH constituye el punto de partida más adecuado para la construcción del nuevo paradigma.

1. La primera reflexión que hemos de hacer consiste en señalar que la cuestión de los límites legales impuestos a determinados derechos fundamentales debe resolverse, por supuesto, partiendo de que el fin del Estado es la garantía de los Derechos fundamentales de la persona. Las modernas democracias encuentran su antecedente filosófico-político próximo en los dos «Ensayos sobre el Gobierno Civil» y restante obra de John Locke, y no en el «Leviatán» de Thomas Hobbes $^{58}$. La seguridad está al servicio de la libertad y no viceversa.

Pero esta perspectiva genérica no resuelve los problemas que se plantean, pues por una parte, los límites a los derechos impuestos por razón de la lucha contra el terrorismo pueden contemplarse no ya desde el punto de vista de la seguridad nacional, sino desde el propio punto de vista de los Derechos fundamentales: es el derecho a la vida, a la integridad física y a la seguridad de las personas el que se protege; por esto, de otro lado, el valor seguridad no debe ser contemplado sin más como antitético del valor libertad. Basta asomarse a los teóricos de la justicia y del Derecho para constatarlo. Así, en la obra de John Rawls, en su "Teoría de la justicia»" ${ }^{59}$ se sostiene la complementariedad de la libertad y de la seguridad, acentuándose que si las leyes son inseguras, la libertad también es insegura, que la libertad, para ser plenamente tal, ha de ser segura. Y si nos remontamos al pensamiento de Cesare Beccaría, en su obra «De los delitos y las penas", fundamento del Derecho penal moderno, del que se ha dicho que no es sino el reverso de la Constitución, ya decía que la incertidumbre acerca de la conservación de la libertad puede convertir a ésta en inútil.

58 Torres del Moral, Antonio, «Libertades públicas y fuerzas de seguridad», en Constitución y seguridad pública: una reflexión a los veinticinco años, Madrid, Ministerio del Interior, 2005, páginas 25 y siguientes.

59 Rawls, John, «Teoría de la justicia», Fondo de Cultura Económica, 2. a edición, 1995, pp. 201 y ss. 
2. Pasamos al segundo punto: los tres paradigmas clásicos y el estado de tensión.

La base de Guantánamo responde al paradigma de la guerra, mientras que la respuesta europea al terrorismo se orienta hacia el paradigma del derecho penal.

La guerra global contra el terrorismo es para la Administración Bush, una guerra $^{60}$. Nada más cometerse el atentado del 11 de septiembre de 2001, el mismo fue calificado de acción de guerra. Los aliados de EE UU en la OTAN, incluida España, llegaron a la misma conclusión y activaron la aplicación del artículo 5 a fin de que el ataque del 11-S fuera jurídicamente interpretado como un a ataque a todos los aliados. Al ser calificada jurídicamente como guerra la que había que combatir contra el terrorismo, los prisioneros que se hicieran en ella tendrían que ser prisioneros de guerra, sometidos, por tanto, a sus leyes.

Lo que ha ocurrido es que, las democracias europeas, al tener que enfrentarse con el fenómeno del terrorismo, han preferido más bien considerarlo como un problema criminal con el fin de deslegitimar a los terroristas como enemigos a base de tratarlos como vulgares delincuentes. Los atentados de 14 de marzo de 2004 en Madrid y de 7 de julio de 2005 en Londres no provocaron la misma respuesta que la de EE UU a los atentados de las torres gemelas. Pero en aquél país, no ya los congresistas republicanos, sino 18 representantes y 12 senadores demócratas votaron a favor de la Ley de Comisiones Militares, fruto directo del planteamiento jurídico de Bush para luchar contra el terrorismo.

Quizás convenga señalar incidentalmente que la crítica que se suele dirigir al modelo de Bush, y en particular a la base de Guantánamo se manifiesta sin embargo dirigiéndole a veces reproches poco matizados e incluso contradictorios entre sí.

En efecto, muchas de las críticas que desde Europa se han hecho a la política de Bush con respecto a los detenidos de Guantánamo se fundan en la consideración de que a tales detenidos se les debían reconocer los derechos que el ordenamiento jurídico norteamericano establece para los presuntos delincuentes. Esta acusación carece para la Administración Bush de suficiente base jurídica desde el momento en que los detenidos de Guantánamo son prisioneros de guerra.

${ }^{60}$ Para lo que sigue nos hemos basado en las consideraciones de Campmany, Emilio, «Las Comisiones militares. Guantánamo. Derecho y estrategia en la Guerra contra el Terrorismo (I)», en la página web del Grupo de Estudios Estratégicos (GEES), Colaboraciones, n. ${ }^{\circ}$ 1293, pp. 4 y ss. Que nos hayamos basado en este trabajo, especialmente útil por la claridad del mismo y por la precisión de la información que proporciona no quiere decir que hagamos nuestras las opiniones que vierte. Así, la postura del autor de este trabajo se emplea en el nuestro para sistematizar la postura de la Administración estadounidense. 
Además, nótese que esta exigencia (de aplicación del derecho penal y procesal comunes) sólo puede ser coherente si, con carácter previo, se afirma que los EE UU no están en guerra con las organizaciones terroristas. Sin embargo, los críticos, reclaman al tiempo el respeto a las Convenciones de Ginebra, cuya aplicabilidad exige, como presupuesto lógico, la existencia de un conflicto armado.

También conviene recordar, para explicar la fundamentación jurídico-positiva de la política antiterrorista de Bush que, según las Convenciones de Ginebra, los Estados firmantes tienen derecho a mantener detenidos a los combatientes enemigos que capturen durante todo el tiempo que duren las hostilidades. A estos efectos, para el Ejecutivo estadounidense, la acusación de que algunos detenidos en Guantánamo no han cometido ningún acto terrorista contra los EE UU y debieran ser en consecuencia puestos en libertad ignora que, cuando las Convenciones de Ginebra permiten la detención de los prisioneros de guerra, no lo hacen para permitir al Estado captor castigarlos por haber combatido contra él, sino porque es derecho de todo Estado beligerante detener a los combatientes enemigos que capture e impedir que lo combatan en el futuro. Se trata pues de una detención preventiva, no punitiva. Esto exige ser puestos en libertad cuando éstas finalizan. No hay delito que enjuiciar, ni proceso penal que seguir. Para la Administración Bush, son combatientes enemigos y su detención, hasta el fin del conflicto, está perfectamente autorizada por las Convenciones de Ginebra.

En definitiva, ni el modelo del Derecho de la guerra ni el modelo del Derecho penal y procesal clásico, sirven para dar una respuesta acabada al terrorismo actual. Así lo han señalado, en EE UU, Bruce Ackerman, en su artículo titulado "The emergency constitution», primero publicado en la revista de la Universidad de Yale, luego como libro en Italia ${ }^{61}$ y en España ${ }^{62}$, y, en Europa Jurgen Habermas, en su obra traducida al castellano con el expresivo título de «El occidente escindido" ${ }^{63}$.

La respuesta tampoco está en el Derecho de excepción clásico, pues, si pensamos en el propio de los países anglosajones, como razona Ackerman, ni el terrorismo actual amenaza la existencia del Estado o de manera abierta la continuidad del régimen, ni puede admitirse un estado excepcional cada vez que haya un atentado terrorista, pues las secuelas de dichos Estados se prolongan duran-

${ }^{61}$ Ackerman, Bruce, La Constituzione di emergenza. Come salvaguardare libertà e diritti civili di fronte al pericolo del terrorismo, Meltemi, Roma, 2005, traducción del artículo «The Emergency Constitution", en The Yale Law Journal, 2004, vol. 113, pp. 1029-1109.

62 Antes de que nos ataquen de nuevo. La dfensa de las libertades en tiempos de terrorismo, Ediciones Península, Barcelona, 2007.

63 «El occidente escindido», Trotta, Madrid, 2006, pp 113 y ss. 
te unos diez años, con lo que unos cuantos atentados de grandes dimensiones podrían acabar en cincuenta años con el Régimen de libertades. Tampoco está la respuesta en el estado de excepción propio de los países continentales europeos, como lo prueba el hecho de que ellos mismos no acudan a proclamarlo por causa de atentados terroristas, lo que se explica porque dichos atentados en definitiva no amenazan la existencia del Estado ni la continuidad del régimen.

La amenaza terrorista crea una situación nueva que ha sido llamada por Rosenfeld ${ }^{64}$ estado de tensión. Los períodos de tensión no son ni tiempos normales ni tiempos de crisis. En el contexto de una crisis, ya sea militar, económica, social o natural, el jefe de Gobierno puede tener habilitación para declarar poderes excepcionales y suspender derechos constitucionales, incluyendo los derechos políticos. En una crisis de suma gravedad, el Gobierno se centra esencialmente en la supervivencia, y el resto de las preocupaciones y los objetivos políticos pasan a un segundo plano.

Los tiempos de tensión se sitúan en un punto intermedio entre los tiempos normales y los de crisis. En tiempos de tensión existe un menor grado de integración y acuerdo en la concepción del bien común. La comunidad política une a los ciudadanos y no se desintegra, pero sí se ve desestabilizada y sometida a diversas presiones. Mientras que una guerra convencional puede provocar una crisis, parece más probable que el terrorismo y la lucha contra el mismo originen tensión.

La respuesta probablemente está en un sistema nuevo que se va construyendo poco a poco que puede consistir en cuidadosos retoques de las leyes penales y procesales, que deben encontrar anclaje en el texto constitucional. Y acaso también, en un nuevo derecho de excepción que tenga en cuenta los postulados de la propuesta de Ackerman.

En efecto, Ackerman ${ }^{65}$ ha lanzado una propuesta de configuración de un nuevo estado de emergencia cuyas líneas maestras son simples y al mismo tiempo creativas. Pensar en un estado de emergencia desde una perspectiva demo-

${ }^{64}$ En este punto seguimos muy de cerca las observaciones de Rosenfeld, Michel, «iEs apropiada la ponderación judicial en la lucha contra el terrorismo? Contrastando tiempos normales, emergencias y tiempos de tensión", en Real Instituto El Cano de Estudios Internacionales y Estratégicos, Área: Terrorismo Internacional, ARI n. ${ }^{\circ}$ 109/2005 (Trad. Inglés), fecha 19/09/2005, en la página web del Real Instituto El Cano: www.realinstitutoelcano.org. Ahora bien, mientras que Rosenfeld habla de diferentes paradigmas en la ponderación judicial de la legislación antiterrorista, nosotros consideramos que lo que debe estar sujeto a un régimen jurídico peculiar o paradigma específico es tanto el tratamiento constitucional, como el legislativo y el judicial. También alteramos en algunos detalles la descripción de Rosenfeld de algunos paradigmas.

65 Ackerman, Bruce, La Constituzione di emergenza. Come salvaguardare libertà e diritti civili di fronte al pericolo del terrorismo, Meltemi, Roma, 2005, pp. 38 y ss. 
crática significa situar en su línea constitutiva en primer lugar la provisionalidad. Un estado de emergencia o de excepción debe contener el máximo de garantías de que la normalidad deberá regresar lo más rápidamente posible. El instrumento principal ideado por Ackerman para realizar este principio es vincular la institución y el mantenimiento del estado de emergencia al consenso de mayorías cualificadas progresivamente crecientes. En su esquema el ejecutivo tiene una autonomía mínima para declarar el estado de emergencia — no más de dos semanas - y es la asamblea legislativa la que ha de convalidar tal decisión en caso de que se estime necesaria una prolongación en el tiempo de la misma, también por un tiempo limitado, que nunca debe superar los dos meses. Para las sucesivas confirmaciones del estado de emergencia, que habrían de tener lugar con intervalos de dos meses, la mayoría necesaria crecería un diez por ciento, hasta alcanzar el 80 por ciento, porcentaje en el que se estabilizaría. De esta manera, se minimiza la posibilidad de que un ejecutivo fuerce la mano de la cámara legislativa, al menos en uno de los clásicos sistemas bipartidistas o bipolares. Una minoría del 21 por ciento tendría poder para acabar con el estado de emergencia.

En segundo lugar, por definición, el estado de emergencia confiere mayores poderes al gobierno en cuestión. Esto requiere un contrapeso constitucional. Este contrapeso lo encuentra Ackerman en la atribución a la oposición de un poder, constitucionalmente garantizado, de vigilancia sobre la información. Afín del logro y del mantenimiento de las mayorías parlamentarias tan amplias, la función de la información hecha pública resulta crucial. Si el gobierno tiene las manos libres para imponer el secreto respecto de datos o informaciones fundamentales, el juego de la emergencia estaría trucado a su favor. Por tanto, corresponderá a la oposición, bajo su responsabilidad, controlar y asumir decisiones respecto a la información y al pluralismo de los medios de comunicación social.

En tercer lugar, si estado de emergencia significa más poderes para el ejecutivo y menos garantías en el ámbito de los derechos, es evidente que se producirán víctimas de la acción de lucha contra el terrorismo, inocentes injustamente acusados, en una medida directamente proporcional mayor respecto de los tiempos normales en que actúan plenamente las garantías legales y constitucionales. Aquí Ackerman propone elevar incluso a 60 días la detención preventiva en espera del primer juicio de los acusados de terrorismo. Pero en su propuesta se pone énfasis en la idea de una justa indemnización así como reflexiones de gran interés acerca del papel que la magistratura puede jugar en la regulación de la máquina de la emergencia en su conjunto.

3. El siguiente punto es la necesidad de un anclaje constitucional del estado de tensión o de la legislación especial. Desde esta perspectiva, esto es, aceptando 
la necesidad de una regulación especial del terrorismo, así como la conveniencia de que dicha regulación tenga un fundamento constitucional, nuestro art. 55.2 CE habría de dejar de ser contemplado como un precepto del que casi nos tenemos que avergonzar para pasar a ser contemplado y estudiado como una aportación de nuestra Constitución vigente al constitucionalismo democráticoliberal, pues se trata del primer precepto de este tipo en una Constitución demo-liberal y normativa.

Seguramente a la altura de 1978 nuestro país no podía incorporar novedades significativas en el texto constitucional que hicieran discutible la homologación del mismo con los textos constitucionales de las democracias consolidadas. Esto explica que en aquel momento se introdujera con cierta dificultad el art. 55.2 CE, y que después el desarrollo del mismo se haya tenido que realizar de manera vergonzante. Por otra parte, es de lamentar que una de nuestras aportaciones al constitucionalismo pueda ser, tristemente, un precepto constitucional que posibilite la introducción de limitaciones a los derechos fundamentales por razón del terrorismo, diferentes de las que pudieran suponer las instituciones que se muevan en el ámbito del clásico derecho excepcional. Sin embargo, en la actualidad, cuando todos las democracias consolidadas se están viendo obligadas a introducir reformas legislativas de discutible anclaje en la Constitución, y cuando en particular, en Estados Unidos se está desarrollando un debate entorno a la conveniencia de reformar la Constitución en este sentido, nuestro país, y en particular la Constitución de 1978, ha de señalarse como pionera en este punto.

El terrorismo, como tal, sólo ha sido contemplado explícitamente en una Constitución democrático liberal: la nuestra vigente. Pero nuestro art. 55.2 $\mathrm{CE}$, hasta el momento, en lugar de ser contemplado como una aportación nuestra al constitucionalimo digna de ser exhibida, ha sido considerado por la doctrina y por el legislador más bien como un precepto casi anómalo, que finalmente se ha renunciado a desarrollar explícita y abiertamente.

4. Punto irrenunciable en la configuración del nuevo paradigma es el principio de universalidad de de los derechos humanos, que se ha concretado en el hecho de que el propio Tribunal Supremo de Estados Unidos disponga la aplicación extensiva del art. 3 común de las Convenciones de Ginebra a los detenidos de Guantánamo.

Del mismo modo que las declaraciones de los derechos humanos y de los derechos fundamentales concretos surgieron de alguna manera como respuestas históricas a la vulneración de los correspondientes derechos, parece que en la actualidad emerge como un principio jurídico el de universalidad de los derechos 
humanos, como respuesta a la negación de esta característica esencial de los mismos.

Este principio jurídico es más amplio que la universalidad del Derecho Internacional de los derechos humanos y tiene como concreciones actuales la afirmación de que en el mundo no hay «limbos jurídicos» en los que no se aplique el Derecho.

Se refuerza la tesis del carácter esencial de la idea de universalidad en la génesis de los derechos humanos si tenemos presente el pensamiento de uno de los autores clave de la filosofía jurídico-política de la Ilustración, de un pensador que en cierto modo resume y culmina la cultura de este período: Immanuel Kant. En el opúsculo Sobre la Paz Perpetua ${ }^{66}$ Kant postuló la creación de un Estado mundial, que se viene a concebir igualmente como una república, como el conjunto de todas las repúblicas federadas, que se caracterizan por el reconocimiento de los derechos individuales, en particular la libertad y la igualdad.

5. Para la configuración del nuevo paradigma, es obvio que desde la anterior perspectiva ofrece mejor punto de partida la experiencia europea que la estadounidense. Ha de destacarse en tal sentido la jurisprudencia del $\mathrm{TEDH}^{67}$. Esta jurisprudencia ha fijado diversos principios referidos a la suspensión de los derechos motivados por la exigencia de combatir eficazmente el terrorismo: inevitabilidad de las suspensiones cuando se rebelen ineficaces remedios ordinarios; aseguramiento del derecho de defensa y de controles jurisdiccionales idóneos sobre las medidas adoptadas y sobre todo sobre las limitadoras de la libertad personal; información a los órganos del Convenio, y posible control del Tribunal. Pero además el TEDH tiene un cuerpo de doctrina en materia de limitación de los derechos fundamentales por razón de la lucha contra el terrorismo que ya podemos considerar clásico y que, siguiendo la elaboración doctrinal de Schutter, podemos sintetizar señalando las siguientes notas.

En primer lugar, la seguridad es un derecho fundamental y se deriva de ello que para el CEDH la protección de la misma es un deber del Estado.

Segundo. Sin embargo, las necesidades de la lucha contra el terrorismo encuentran sus límites en la obligación de los Estados parte en el Convenio de respetar los derechos y libertades que el Convenio reconoce a las personas que se

${ }^{66}$ Traducción de Joaquín Abellán y presentación de Antonio Truyol Serra, Madrid, Tecnos, 1985.

${ }^{67}$ Las siguientes consideraciones se basan en el trabajo de Schutter, Olivier de, «La Convention européenne des droits de l'homme à l'épreuve de la lutte contre le terrorisme» en Revue Universelle de Droits de l'Homme, vol.13, n. ${ }^{\circ}$ 5-8, 2001, pp. 185 y ss. 
encuentren bajo su jurisdicción: las restricciones a los derechos están justificadas únicamente en la medida en que dichas restricciones sean admisibles en virtud del régimen regulador de estos derechos.

Tercero, debe tenerse en cuenta que para el TEDH existen derechos absolutos que no admiten restricción alguna, como la prohibición de la tortura o el derecho a la vida.

Cuarto. Sin embargo, es sobre todo en el marco de la interpretación que ha hecho de los derechos y libertades más clásicos, ya no formulados en términos absolutos, donde el TEDH ha reconocido la especificidad de la lucha antiterrorista. El Tribunal Europeo de Derechos Humanos subordina la admisibilidad de las diversas restricciones que pueden realizarse a los derechos del individuo por razón de la lucha contra el terrorismo - tanto si se trata de la limitación de la esfera de intimidad, de la interceptación de sus comunicaciones, del tratamiento de datos de carácter personal, del recurso a técnicas de infiltración o a testimonios anónimos, o de la privación de la libertad - a la adopción por las autoridades nacionales de medidas compensatorias de estas restricciones y que, en particular, comprendan las garantías procesales adecuadas para limitar el riesgo de abuso.

La facultad que el art. 15 del Convenio reconoce a los Estados de «derogar» o suspender determinados derechos del Convenio cuando un peligro público amenace la vida de la Nación no permite eludir verdaderamente estos límites impuestos a la lucha contra el terrorismo, por cuanto el referido art. define rigurosamente los requisitos de la suspensión.

La jurisprudencia del Tribunal Europeo de Derechos Humanos en materia de limitaciones de derechos fundamentales por razón del terrorismo, con posterioridad a los atentados de 11 de septiembre de 2001, en principio, se ha mantenido en la misma línea, sin que se haya renunciado a los postulados esenciales. Así lo ha proclamado en algún caso el Tribunal expresamente. Por ejemplo, en la STEDH de 26 de enero de 2007, Asunto Chraidi v. Alemania, parágrafo 37, en la que no obstante hay un relativo distanciamiento de la jurisprudencia anterior, que el Tribunal justifica por las particulares circunstancias del caso.

\section{Title}

Anti-terrorist constitution and legislation

\section{Resumen}

El presente trabajo tiene por objeto el estudio del régimen jurídico del terrorismo, prestando particular atención a las principales resoluciones 
que han dictado tribunales supremos significativos, en relación con dicho fenómeno, y más concretamente las dictadas tras los atentados de 11 de septiembre de 2001. En una primera parte se alude a las transformaciones legislativas que ha comportado la lucha contra el terrorismo. En una segunda parte se analizan las principales sentencias recaídas sobre la materia. La tercera parte contiene una serie de reflexiones entre las que cabe destacar la idea fundamental de que debe confeccionarse en este ámbito un nuevo paradigma: el de las situaciones de tensión. Y que elementos esenciales de ese paradigma son el principio de universalidad de los derechos humanos y la jurisprudencia del Tribunal Europeo de Derechos humanos (TEDH en lo sucesivo).

\begin{abstract}
The present work has the aim of studying the judicial set of rules for terrorism, paying particular attention to the principal resolutions that the important supreme tribunals have dictated in relation to such phenomenon, specifically those dictated after the attacks of 11 of September 2001. The first part alludes to the legislative transformations that war against terrorism has involved. The second part analyzes the main sentences passed on about the subject. The third part contains a series of reflections, amongst which the fundamental idea that a new paradigm should be made in this field is outstanding: that of tension situations. And that the essential elements of that paradigm are the principle of universality of the human rights and the jurisprudence of the European Court of Human Rights (ECHR from now on).
\end{abstract}

\title{
Palabras clave
}

Antiterrorismo. Suspensión de garantías. Estado de emergencia. Tribunal Supremo de Estados Unidos. Derecho penal del enemigo

\section{Key words}

Anti-terrorism. Suspension of guarantees. State of emergency. Supreme Court of the United States of America. Criminal Law of the Enemy 